Review

\title{
Growth and Nutritional Quality of Lemnaceae Viewed Comparatively in an Ecological and Evolutionary Context
}

\author{
Barbara Demmig-Adams ${ }^{1, *}$, Marina López-Pozo ${ }^{2}$, Stephanie K. Polutchko ${ }^{1}\left(\mathbb{C}\right.$, Paul Fourounjian ${ }^{1,3}$, \\ Jared J. Stewart ${ }^{1}{ }^{\circledR}$, Madeleine C. Zenir ${ }^{1}$ and William W. Adams III ${ }^{1}[$ \\ 1 Department of Ecology and Evolutionary Biology, University of Colorado, Boulder, CO 80309, USA; \\ Stephanie.Polutchko@Colorado.EDU (S.K.P.); paul@internationallemnaassociation.org (P.F.); \\ Jared.Stewart@Colorado.EDU (J.J.S.); Madeleine.Zenir@colorado.edu (M.C.Z.); \\ William.Adams@colorado.edu (W.W.A.III) \\ 2 Department of Plant Biology and Ecology, University of the Basque Country (UPV/EHU), 48049 Bilbao, \\ Spain; marinalopezpozo@hotmail.com \\ 3 International Lemna Association, Denville, NJ 07832, USA \\ * Correspondence: Barbara.Demmig-Adams@Colorado.EDU; Tel.: +1-303-492-5541
}

Citation: Demmig-Adams, B.; López-Pozo, M.; Polutchko, S.K.; Fourounjian, P.; Stewart, J.J.; Zenir, M.C.; Adams, W.W., III. Growth and Nutritional Quality of Lemnaceae Viewed Comparatively in an Ecological and Evolutionary Context. Plants 2022, 11, 145. https://doi.org/ $10.3390 /$ plants 11020145

Academic Editors: Viktor Oláh, Klaus-Jürgen Appenroth and K. Sowjanya Sree

Received: 14 November 2021

Accepted: 4 January 2022

Published: 6 January 2022

Publisher's Note: MDPI stays neutral with regard to jurisdictional claims in published maps and institutional affiliations.

Copyright: (c) 2022 by the authors. Licensee MDPI, Basel, Switzerland. This article is an open access article distributed under the terms and conditions of the Creative Commons Attribution (CC BY) license (https:// creativecommons.org/licenses/by/ $4.0 /)$.

\begin{abstract}
This review focuses on recently characterized traits of the aquatic floating plant Lemna with an emphasis on its capacity to combine rapid growth with the accumulation of high levels of the essential human micronutrient zeaxanthin due to an unusual pigment composition not seen in other fast-growing plants. In addition, Lemna's response to elevated $\mathrm{CO}_{2}$ was evaluated in the context of the source-sink balance between plant sugar production and consumption. These and other traits of Lemnaceae are compared with those of other floating aquatic plants as well as terrestrial plants adapted to different environments. It was concluded that the unique features of aquatic plants reflect adaptations to the freshwater environment, including rapid growth, high productivity, and exceptionally strong accumulation of high-quality vegetative storage protein and human antioxidant micronutrients. It was further concluded that the insensitivity of growth rate to environmental conditions and plant source-sink imbalance may allow duckweeds to take advantage of elevated atmospheric $\mathrm{CO}_{2}$ levels via particularly strong stimulation of biomass production and only minor declines in the growth of new tissue. It is proposed that declines in nutritional quality under elevated $\mathrm{CO}_{2}$ (due to regulatory adjustments in photosynthetic metabolism) may be mitigated by plant-microbe interaction, for which duckweeds have a high propensity.
\end{abstract}

Keywords: chlorophyll fluorescence; electron transport chain; inflammation; lutein; photosystem; photosynthetic capacity; relative growth rate

\section{Introduction}

The smallest known flowering plants are found in the Lemnaceae family and are recognized (see recent comprehensive review by Acosta et al. [1]) for their attractive combination of extremely high growth rates [2,3] with high nutritional quality, including a high protein content, with all essential amino acids for humans, as well as a high content of essential human micronutrients [4]. The Lemnaceae, commonly known as duckweeds, water lentils, or water lenses, are comprised of five genera, including Lemna and Wolffia [1]. The high protein content of Lemnaceae is associated with their propensity for the efficient uptake and accumulation of nitrogen and other mineral nutrients, which makes them good at wastewater recycling [5-9] and contributing to a high nitrogen-use efficiency in agricultural contexts [10].

Additional traits of interest include duckweed's ability to accumulate high levels of starch as well as their relatively low susceptibility to the undesirable effects of elevated atmospheric carbon dioxide levels (for details, see sections dedicated to these topics below). Moreover, duckweed's rapid growth and diminutive size allow for a high volumetric yield 
in tight quarters such as greenhouses, urban rooftop growth facilities, and spacecrafts, where duckweed's insensitivity to microgravity is another boon $[1,11]$. Our review places the above traits, as well as additional traits recently described by our group, into the context of the ecology and evolution of Lemnaceae in comparison with terrestrial plants as well as other floating aquatic plants.

The traits of Lemna recently characterized by us, which are the focus of this review, include:

- The pronounced tolerance of a wide range of growth light intensities and a remarkable capacity to accumulate high levels of antioxidant micronutrients, such as the essential carotenoid zeaxanthin, due to an unusual pigment composition not seen in fastgrowing land plants.

- The response to elevated $\mathrm{CO}_{2}$ as evaluated in the context of plant metabolic regulation of the source-sink balance (balance between the plant's sugar production and consumption), carbon-to-nitrogen ratio, and redox homeostasis (balance of oxidants and antioxidants).

\section{Exceptions to Common Trade-Offs: Araceae and Lemnaceae}

\subsection{Trade-Off between the Ability to Grow in Deep Shade and Full Sun}

Many land plants exhibit a trade-off between the ability to tolerate deeply shaded growth environments on the one hand and extremely high light levels on the other. Specifically, fast-growing species are typically sun-loving and unable to grow in deep shade. Exceptions are found in the family Araceae, which belongs to the same order (Alismatales, water plantains) as the Lemnaceae. The Alismatales include many floating or submersed aquatic and wetland species found in marshy and marine habitats [12]. Araceae is the most species-rich family of the Alismatales and is remarkable for the highly diverse habitats in which its species thrive, ranging from open freshwater to deserts, and its diverse life forms, including hemi-epiphytes, epiphytes, terrestrial species, and aquatic plants [13]. It has been noted that some Araceae exhibit a high level of flexibility in the organization of the photosynthetic membrane [14] (see also below).

Plants can suffer damage from intense light unless they process absorbed light either in photosynthesis (which converts excitation energy to chemical energy) or via safe alternative processes (that, e.g., convert excitation energy to harmless thermal energy; see $[15,16])$. Many species in the Araceae can grow equally well in deep shade and in full sun (see $[16,17])$. For example, the hemi-epiphyte Monstera deliciosa (Araceae) germinates in deep shade on the rainforest floor, climbs the nearest tree, and eventually completes its life cycle in the sun-flooded forest canopy after shedding its connection to the soil. In full sun, M. deliciosa exhibits low rates of photochemical energy utilization but record rates of the alternative, non-photochemical dissipation of absorbed light as thermal energy [17]. This latter process is catalyzed by antioxidants with critical roles in fighting radiation damage in both plants and humans (for details, see sections below).

\subsection{Common Trade-Off between Fast Growth and Antioxidant Accumulation}

Terrestrial plants typically show a trade-off between growth rate and the accumulation of radiation-fighting antioxidants, especially the carotenoid zeaxanthin [16]. Fast-growing terrestrial species tend to accumulate less zeaxanthin, whereas slow-growing species tend to accumulate more zeaxanthin (Figure $1 ;[16,18])$. This difference in response is the expected result of the above-described link to the fraction of absorbed light processed in photosynthesis. Fast-growing species use a greater fraction of the light they absorb at peak irradiance to support growth and accumulate less of the antioxidant zeaxanthin, which harmlessly removes light not usable for growth, i.e., excess light [16,18]. Conversely, slow-growing species (e.g., M. deliciosa) use a lesser fraction of absorbed light for growth and accumulate more zeaxanthin (Figure 1; $[16,18]$ ). The Araceae are thus no exception to the general rule of a trade-off between fast growth and accumulation of high levels of zeaxanthin $[17,19]$. 


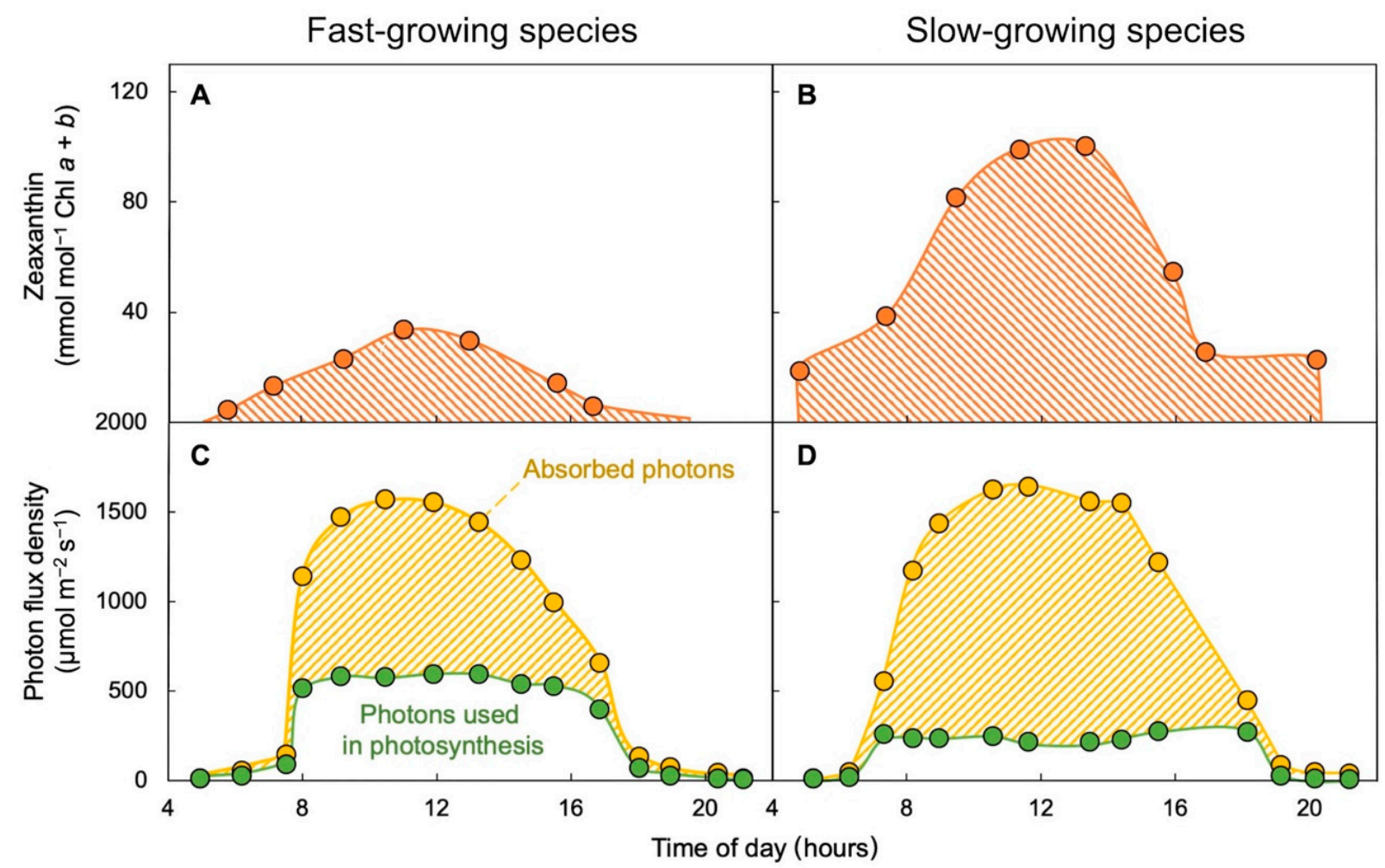

Figure 1. Diurnal time course of changes in $(\mathbf{A}, \mathbf{B})$ zeaxanthin level and $(\mathbf{C}, \mathbf{D})$ photons absorbed and utilized through photosynthetic electron transport in $(\mathbf{A}, \mathbf{C})$ the fast-growing annual crop Helianthus annuus (sunflower) versus (B,D) the slow-growing perennial Vinca major. Data from [18]; re-drawn from [16].

\subsection{Zeaxanthin-Essential Human Micronutrient and Hard to Come by in the Diet}

The essential micronutrient zeaxanthin is not easy to come by in the human diet for the very reason that leaves produce zeaxanthin to fight radiation damage only when necessary. The green parts of plants (such as leafy greens) only accumulate zeaxanthin when they need to actively dispose of excessive, potentially damaging light and quickly remove the dissipator zeaxanthin as soon as light levels drop. This dynamic process gives plants the advantage of allowing photosynthesis to return to highly efficient utilization of absorbed light (Figure 1; reviewed in [16]). Food sources of zeaxanthin, other than leafy greens, include egg yolks and yellow corn, which owe their color to the presence of zeaxanthin and the closely related xanthophyll lutein (see, e.g., [20]). However, neither eggs nor corn are particularly suitable for production in limited spaces. In particular, operation of a chicken farm or corn field is not feasible on a spacecraft and may also not be an attractive approach in an urban setting or a greenhouse.

The essential dietary carotenoid zeaxanthin is not only needed to fight radiation damage and system-wide inflammation in humans but also to support mental acuity in healthy young adults (Figure 2; [21,22]). Zeaxanthin enhances basic membrane function in the brain, which supports mental acuity and detoxifies free radicals and other oxidants, which lessens radiation damage and the system-wide inflammation linked to less-than-optimal function, disorders, and diseases. Additional essential micronutrients act synergistically with zeaxanthin in fighting radiation damage and inflammation; zeaxanthin thus works best in a total package-provided by whole foods - with additional plant antioxidants that recycle zeaxanthin for a longer lifetime in inflammation fighting (Figure 2; [22]). Figure 2 places antioxidants with overlapping essential functions in plants and humans into the cycle of oxygen and carbon dioxide exchange, organic nutrients (e.g., protein and antioxidants), and inorganic nutrients (human waste) between photosynthetic and non-photosynthetic 
organisms. Thereby, Figure 2 highlights that duckweed is an excellent plant component for a regenerative life support system on, e.g., a spacecraft (see also [23,24]).

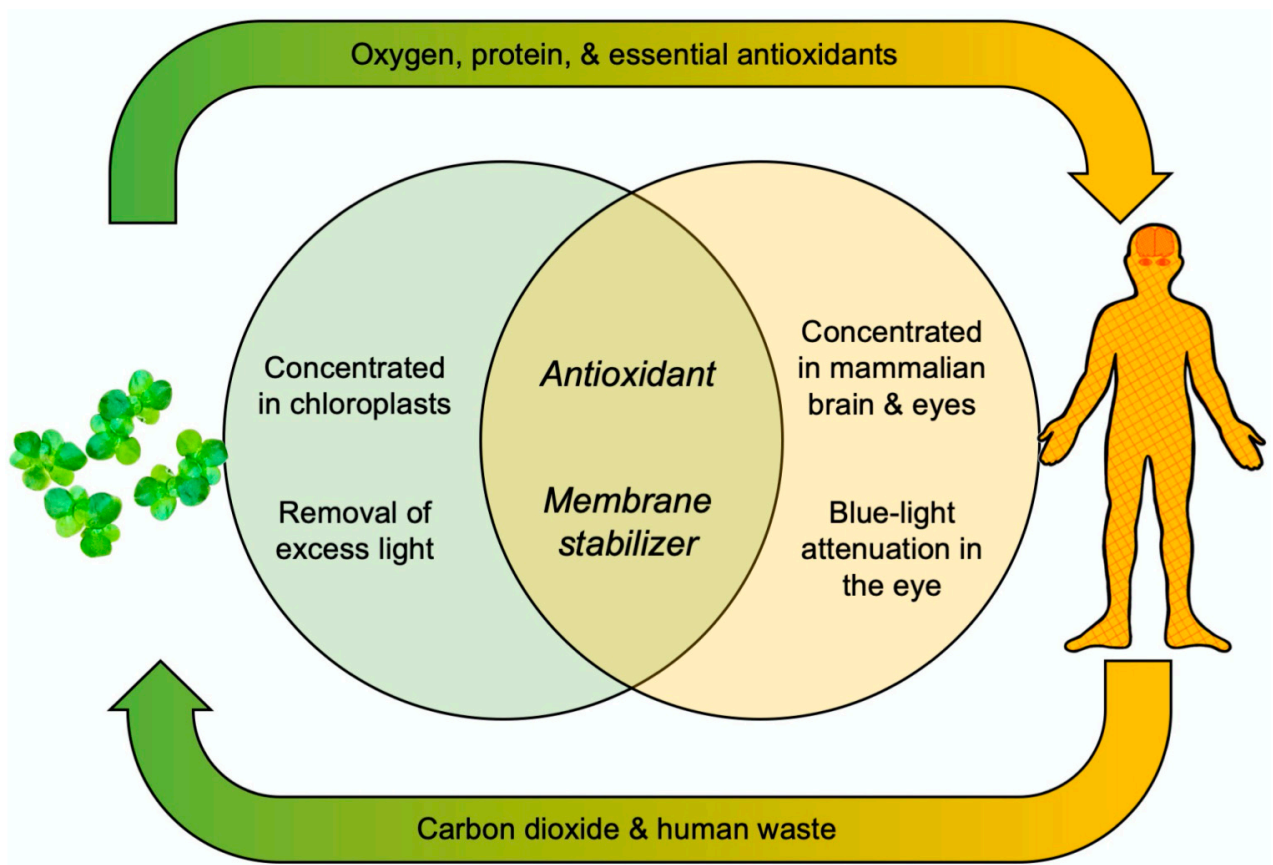

Figure 2. Schematic depiction of the functions of zeaxanthin in plants and humans with both overlapping and analogous aspects.

As reviewed in Demmig-Adams et al. [21], airline pilots (exposed to ionizing radiation) who reported eating more zeaxanthin exhibited less inflammation; similarly, healthy young subjects given zeaxanthin for six months showed less inflammation and enhanced cognitive performance in complex tasks, greater speed at completing those tasks, and better memory and attention. Sufficient dietary zeaxanthin would thus appear to be especially critical for long-duration human spaceflight. As further illustrated in the following section, duckweed provides a renewable food source that can be grown in limited space and can be exceptionally rich in zeaxanthin.

\subsection{Lemna: An Unusual, Fast-Growing Hyperaccumulator of Zeaxanthin}

Among land plants, it is the relatively slow-growing evergreens that typically exhibit the highest zeaxanthin concentrations [16,25]. An extreme example is evergreen conifers that arrest growth completely when they overwinter at high altitude where soil water freezes in the winter. While green needles can absorb a lot of light, they dissipate $100 \%$ of it as thermal energy via zeaxanthin as long as water lost from the needles during $\mathrm{CO}_{2}$ uptake for photosynthesis cannot be replaced [26,27]. As stated above, fast-growing terrestrial annuals instead typically utilize a significant amount of the light they absorb in photosynthesis and do not dissipate as much. When subjected to environmental stresses that can curb their growth rate, such as limiting nutrient levels in the soil [28,29], annuals typically strongly downregulate chlorophyll levels (and thus light-harvesting capacity) and only exhibit moderate increases in zeaxanthin levels employed in energy dissipation. When grown under extreme light conditions (with respect to high intensity and long photoperiod) that resulted in a comparably low chlorophyll content per area, L. gibba accumulated significantly more zeaxanthin $[23,24]$ than spinach grown under limiting nutrient supply $[29,30]$.

Further characterization of Lemna's exceptionally strong zeaxanthin accumulation led to the identification of a carotenoid composition that is unusual for fast-growing plants (Figure 3). A comparison of Lemna with several terrestrial species via principal component 
analysis showed that Lemna fell into the olive-green ellipse of slow-growing plants with high levels of zeaxanthin (and lutein) rather than the blue-green ellipse of other fast-growing plants (Figure 3; [24,25]). In other words, Lemna combines an exceptionally high growth rate with an unusual carotenoid composition and accumulation of as much zeaxanthin as seen in slow-growing land plants (see below).
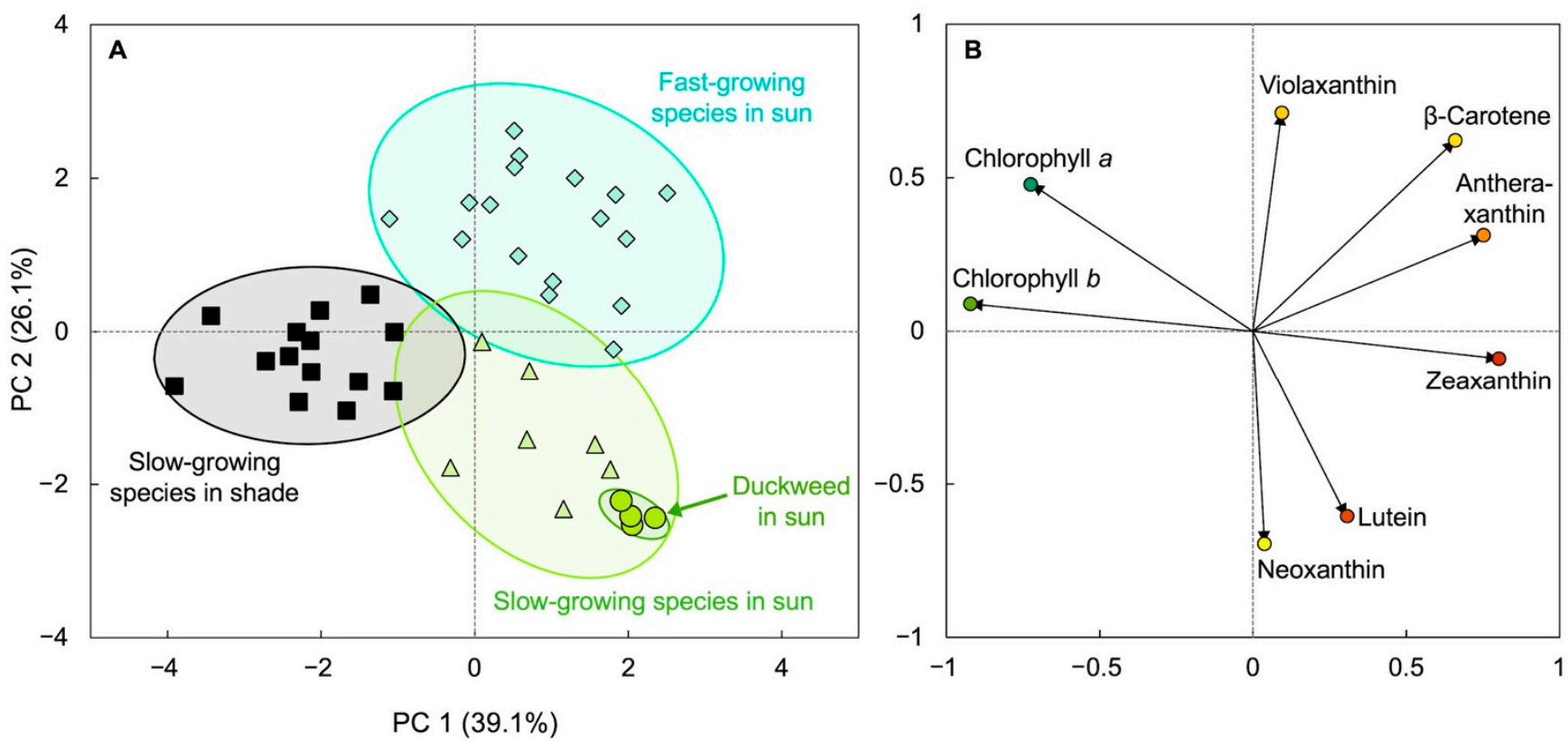

Figure 3. Principal component analysis showing (A) clusters of groups based on similarity (score plot) and (B) how each characteristic used influences a principal component, PC (loading plot). Characteristics used were the various leaf pigments of slow-growing terrestrial species either in shaded environments (black squares) or full sunlight (olive-green triangles), fast-growing (annual and biennial) species (turquoise diamonds) in full sunlight, and duckweed (Lemna minor) that was growing in full sunlight (olive-green circles) near Boulder, CO, USA (for details, see [24,25]). Data from $[24,25]$.

Once again, the traits of duckweed are thus a mix of those seen in slow-growing terrestrial evergreens (with greater maximal zeaxanthin levels) and fast-growing terrestrial annual plants (with lower maximal zeaxanthin levels). Future research is needed to confirm that the high growth rate and the unusually pronounced accumulation of zeaxanthin in Lemna (Figure 4) is associated with thin leaves that likely cause a relatively greater portion of the frond cross-section to be exposed to high light when plants are grown under a high growth light intensity. Terrestrial plants often feature multi-layered canopies, of which only the top leaves receive unfiltered light. Additionally, terrestrial plants typically also feature multi-layered leaves, where only the top cell layer receives unfiltered light. When grown in full sun, leaves of terrestrial plants thus exhibit pronounced high-light acclimation [31], with the highest levels of xanthophylls, and especially zeaxanthin, in their top-most layers [32]. In contrast, duckweed and other floating plants consist of relatively thinner leaves/fronds that presumably experience less attenuation of light from top to bottom. This scenario is supported by the side-by-side comparison of a terrestrial weed with duckweed [24] growing in a high-light exposed location, where the terrestrial weed exhibited a much higher chlorophyll level per unit leaf area typical for that seen in leaves with multiple chloroplast-rich layers of mesophyll cells. 


\section{Low light $\left(50 \mu \mathrm{mol} \mathrm{m} \mathrm{m}^{-2} \mathrm{~s}^{-1}\right)$}

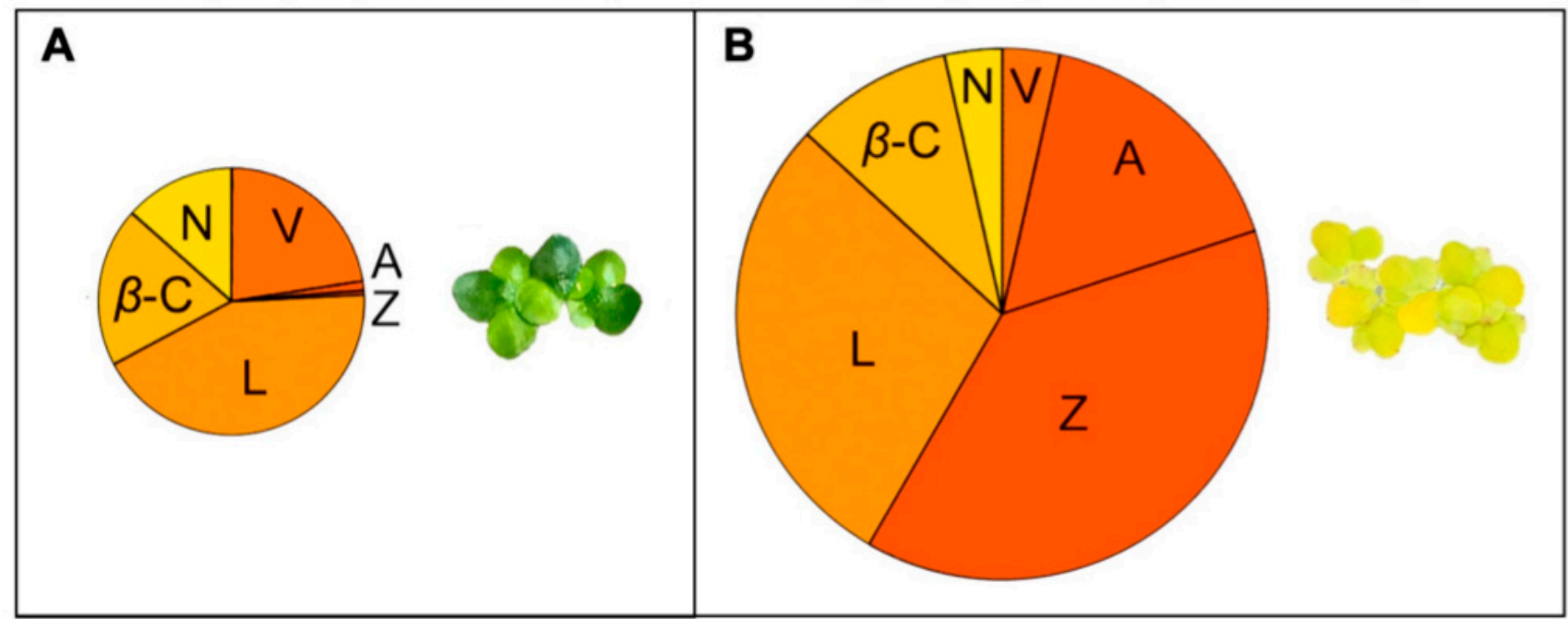

Figure 4. Carotenoid composition of Lemna gibba grown under continuous (A) low or (B) high light intensity. The size of the respective pies represents the molar ratio of the sum of all carotenoids to chlorophyll. Data from [24]; adapted from [16]. A, antheraxanthin, $\beta-C, \beta$-carotene, L, lutein, N, neoxanthin, $\mathrm{V}$, violaxanthin, Z, zeaxanthin.

One can think of duckweed fronds as structures that allow a thin layer of chloroplasts to be uniformly exposed to unfiltered light, which may require unusually high levels of excess-light dissipation and zeaxanthin accumulation under exposure to high light intensities. Hypothetically, duckweed could simply lower its chlorophyll content (and antenna size) enough to avoid absorbing much excess light. However, the maintenance of sufficient chlorophyll levels, accompanied by strong protection from zeaxanthin as needed, may be advantageous to duckweeds that can rapidly shift between being at the top versus in a deeper layer when growing in dense mats.

In addition to being bound to specific designated sites in chlorophyll-binding lightharvesting complexes, additional zeaxanthin can be dissolved in the phospholipid bilayer of plants' photosynthetic membranes outside of chlorophyll-binding proteins (as first reported in [33] and recently reviewed in [34]). The report of a ratio greater than $0.5(\mathrm{~mol} / \mathrm{mol})$ for zeaxanthin to chlorophyll $a+b$ [24] suggests that a substantial fraction of the zeaxanthin accumulated in golden-hued duckweed fronds (Figure 4) growing under continuous high light levels may be dissolved in these membranes rather than being bound to protein complexes. At the same time, this high zeaxanthin content is not associated with sustained lowering of photosystem II efficiency $[23,24]$ as is seen in many plants (see [35] for Arabidopsis thaliana and [16] for evergreens) under environmental stresses. Such a scenario-high zeaxanthin levels uncoupled from sustained lowering of photochemical efficiency - is especially desirable for optimal human nutrition without plant productivity losses. Other aquatic floating flowering plant species (beyond Lemnaceae) have also been reported to exhibit very high levels of xanthophylls [36], although xanthophylls were not separated into zeaxanthin versus other di-hydroxy xanthophylls (like lutein) during these analyses. This possibility that other aquatic plants share the above-described features of duckweed is consistent with a report by Rice [37] that noted aquatic taxa possessed unique photosynthetic features, including pigment composition. Future research should assess these features of aquatic species, which could be of interest for human nutrition, e.g., with respect to zeaxanthin levels. It is noteworthy that many aquatic floating plants are described as edible and/or medicinal plants (see, e.g., [38]). 


\subsection{Remote Sensing of Duckweed Zeaxanthin Content and Biomass Production}

Chloroplast-containing plant organs emit chlorophyll fluorescence, a signal that provides information about the fraction of absorbed light utilized in photosynthesis versus the fraction dissipated alternatively (non-photochemically) in the form of thermal energy. The fraction of absorbed light utilized in photosynthetic electron transport has been used, in conjunction with other parameters, to predict plant productivity (see, e.g., [39]). In terrestrial plants, this relationship is complex ([40,41]; see also the discussion in [24]). However, a simple, linear positive correlation exists in Lemna between this utilization of absorbed light as ascertained from chlorophyll fluorescence (as photosystem II activity per photons) and Lemna biomass production per photons (Figure 5A; [24]). In addition, the activity of non-photochemical, photoprotective energy dissipation assessed from chlorophyll fluorescence is positively and linearly correlated with xanthophyll cycle conversion to zeaxanthin (Figure 5B; $[23,24])$. Chlorophyll fluorescence measurements thus allow non-destructive, remote estimates of zeaxanthin level (see also [16]).
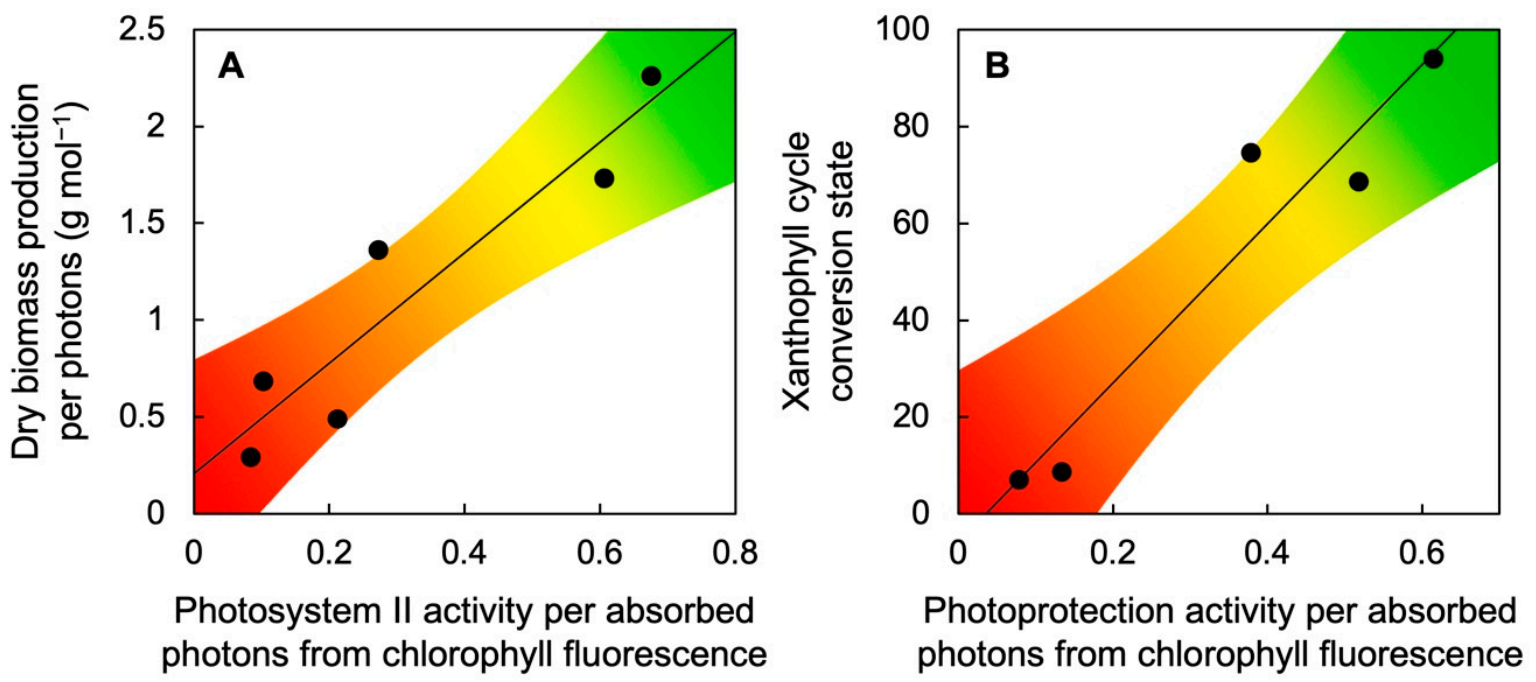

Figure 5. Relationship between (A) dry biomass production per photons and photosystem II activity per absorbed photons from chlorophyll fluorescence (as photosystem II efficiency from $\mathrm{F}_{\mathrm{v}}{ }^{\prime} / \mathrm{F}_{\mathrm{m}}{ }^{\prime} \times \mathrm{q}_{\mathrm{P}}$; see $[18,24])$ or $(\mathbf{B})$ xanthophyll cycle conversion state, $(Z+A) /(V+A+Z)$, and the activity of nonphotochemical dissipation of excess absorbed light from chlorophyll fluorescence (as photoprotective thermal dissipation from $0.8-\mathrm{F}_{\mathrm{v}}{ }^{\prime} / \mathrm{F}_{\mathrm{m}}{ }^{\prime}$; see $\left.[18,24]\right)$ under six different growth-light conditions over a range of light intensities from 50 to $1000 \mu \mathrm{mol}$ photons $\mathrm{m}^{-2} \mathrm{~s}^{-1}$. Data from [23,24]. A, antheraxanthin, $\mathrm{V}$, violaxanthin, $\mathrm{Z}$, zeaxanthin.

\section{Comparative Evaluation of Adaptations in Aquatic and Terrestrial Plants}

\subsection{Rapid Growth in Duckweeds and Other Aquatic Plants}

Lemna grows very fast [3] even under conditions of limited light supply [23,24]. We suggest that this unique feature may be associated with minimal self-shading within its relatively thin photosynthetic organs (fronds) and their single layer of fronds (no tiered structure) across the water surface, which should permit all chloroplasts to contribute significantly to sugar production. Other floating flowering plants also grow remarkably fast $[42,43]$, which may be related to a high allocation of resources to photosynthetic tissue as discussed by Rice [37]. Terrestrial plants growing in soil must invest a sizeable fraction of their photosynthetically produced sugar into building (i) root structures to provide a stable anchor in the soil, for water (and nutrient) acquisition, and for the storage of carbohydrates and (ii) reinforced stem structures for support of the shoot system and transport of water, nutrients, and sugar between their photosynthetic organs and the roots. In contrast, floating plants have minimal non-photosynthetic tissue and can thus re-invest most of their photosynthate into more photosynthetic tissue. The main carbohydrate sink for duckweed 
is vegetative growth, its expanding daughter fronds that also contribute to photosynthetic productivity. Duckweed lacks typical stems or roots that would act as substantial sinks for photosynthate, and its roots can be green and contribute to photosynthesis. It has also been pointed out that Lemnaceae have undergone substantial genome reduction-including gene clusters that control growth [44] in response to the environment in terrestrial plants. Unabated growth of new tissue under a wide variety of environmental conditions is thus duckweed's main sink activity.

\subsection{Continuum of Plant Adaptations to Water Availability}

Another perspective from which to view the fast growth of aquatic plants is their rather continuous access to water. Variable access to water is one of the major environmental variables for terrestrial plants. Many, but not all, terrestrial species curb stomatal opening, and growth, under limiting water as a defense strategy [45]. Such a response would appear less necessary for species that float on water, and duckweeds indeed impose much less control on either stomata or growth rate [44]. A review by Dolferus [46] entitled "To grow or not to grow: A stressful decision for plants" concludes that highly responsive modulation of growth rate-with either slower or faster growth-is one of the major ways for terrestrial plants to respond to changes in water availability. Table 1 compares the response of aquatic floating plants with the continuum of responses of different groups of terrestrial plants.

Table 1. Water-acquisition strategies, growth patterns, and species examples that illustrate the continuum of plant adaptations to water availability.

\begin{tabular}{|c|c|c|c|}
\hline Habitat & Water-Acquisition Strategy & Growth Pattern & Example \\
\hline Aquatic plants & Continuous access to water body until it dries up & Fast growth & Lemnaceae \\
\hline \multirow{6}{*}{$\begin{array}{l}\text { Terrestrial } \\
\text { plants }\end{array}$} & Continuous access to water until source dries up & $\begin{array}{l}\text { Very fast growth and life cycle } \\
\text { completion }\end{array}$ & Desert ephemerals \\
\hline & $\begin{array}{c}\text { Continuous access to water, increased root volume, } \\
\text { osmotic adjustment }\end{array}$ & $\begin{array}{l}\text { Relatively fast growth } \\
\text { throughout life cycle }\end{array}$ & Annuals and biennials \\
\hline & Continuous access to water table & $\begin{array}{l}\text { Steady growth throughout the } \\
\text { seasons }\end{array}$ & Palm and mesquite \\
\hline & $\begin{array}{c}\text { Enhanced acquisition of minimal soil water via } \\
\text { large root volume, osmotic adjustments }\end{array}$ & \multirow{3}{*}{$\begin{array}{c}\text { Slow growth despite minimal } \\
\text { soil water } \\
\text { Very slow growth } \\
\text { Seasonal complete growth } \\
\text { arrest }\end{array}$} & $\begin{array}{l}\text { Desert shrub Encelia, } \\
\text { creosote bush }\end{array}$ \\
\hline & Storage of water in plants & & Succulents, cacti \\
\hline & Tolerance of seasonal loss of water & & Conifers in frozen soil \\
\hline
\end{tabular}

The high growth rate seen in many aquatic plants $[42,43]$ is reminiscent of the high growth rates of terrestrial plants that maintain constant access to water throughout their life cycle (Table 1). Desert ephemerals are an example of terrestrial plants with an extremely high growth rate that rapidly complete their accelerated life cycle after infrequent major rainfall events in arid environments [47]. Other examples for terrestrial plants with high growth rates are annuals and biennials that also complete their life cycle in a relatively short period of time and grow where they can maintain access to water. These species may employ evasive approaches to keep internal water content high, e.g., by performing osmotic adjustment to maintain metabolic activity [48] and increasing their investment in water-mining root structures [49] (Table 1). These terrestrial plants do not put the brakes on growth until water becomes scarce, and then switch to seed production-reminiscent of the production of vegetative storage forms (turions) in Lemnaceae. Yet, other terrestrial plants, such as palm trees or mesquite, have deep roots that access the ground-water table [50-54], which supports steady growth despite low rainfall or moisture level in the air. Pronounced osmotic adjustment [55] and expansion of root volume [56] is also employed by terrestrial plants that grow very slowly in areas with extremely low water availability (Table 1).

Those terrestrial plants that tolerate-rather than evade-internal water deficits exhibit trade-offs between growth rate and stress tolerance/antioxidant content. In extreme 
natural environments, growth is suspended entirely, such as in cold environments with seasonally frozen soils (Table 1), where the green needles of overwintering confers exhibit very high levels of zeaxanthin [26,27]. Many perennial species adapted to seasonally harsh environments grow incrementally over multiple years-by growing actively during favorable seasons and arresting growth during unfavorable seasons. In an agricultural context, unabated growth is desirable, and floating plants with their fast, continuous growth thus offer attractive opportunities that rival those of terrestrial annuals and biennials.

\subsection{Plant Source-Sink Balance and the Response to Light, $\mathrm{CO}_{2}$, and Nutrient Supply}

While both $\mathrm{CO}_{2}$ and light are necessary inputs for photosynthesis, the proverbial "too much of a good thing" with respect to $\mathrm{CO}_{2}$ and/or light can have negative impacts on plant nutritional quality, growth, and plant lifespan. A report by Myers et al. [57] entitled "Increasing $\mathrm{CO}_{2}$ threatens human nutrition" addressed possible adverse effects on plant protein as well as other nutrients. Whereas these impacts on plant nutritional quality for the consumer appear to be rather universal for $\mathrm{C}_{3}$ species, other possible impacts of elevated $\mathrm{CO}_{2}$ vary among species and with environmental conditions and include possible disruption of photosynthetic productivity as well as accelerated senescence (for a recent review, see [58]). In the following, we examine the possibility that duckweed may be less sensitive to the possible adverse effects of elevated $\mathrm{CO}_{2}$ on plant productivity than many other species. We first discuss the effect of elevated $\mathrm{CO}_{2}$ on protein (as well some micronutrients) in the context of plant source-sink balance. Photosynthetic organs are the plant's only source of newly formed carbohydrates, whereas all sugar-consuming tissues are sugar sinks. The maximal capacity of photosynthesis is regulated by the demand for sugar from the plant's sink tissues $[30,59,60]$. This regulation by demand is well described for terrestrial plants; excess carbohydrate build up in the leaves leads to downregulation of photosynthetic capacity, which can be the case under conditions of elevated atmospheric $\mathrm{CO}_{2}$ and especially in combination with additional environmental factors that cause sourcesink imbalances (see, e.g., [61]). Lemna exhibits some of the responses described for land plants with respect to the content of protein and micronutrients under very high light and/or $\mathrm{CO}_{2}$ supply (see below).

Under moderate supply of light and earth-ambient $\mathrm{CO}_{2}$, light drives photosynthetic electron transport and allows $\mathrm{CO}_{2}$ to be fixed into sugar as the fuel for growth. A combination of high light supply and elevated $\mathrm{CO}_{2}$ produces more sugar than is consumed by sink tissues, which leads to feedback inhibition (Figure 6) with build-up of carbohydrate in leaves, backed-up electrons in the photosynthetic electron transport chain, and formation of increased levels of reactive oxygen species (ROS) that are potent repressors of photosynthetic and other genes [62-65]. An extreme level of foliar carbohydrate build-up and ROS production under elevated $\mathrm{CO}_{2}$ can curb the growth of new tissue and accelerate plant senescence [66]. 


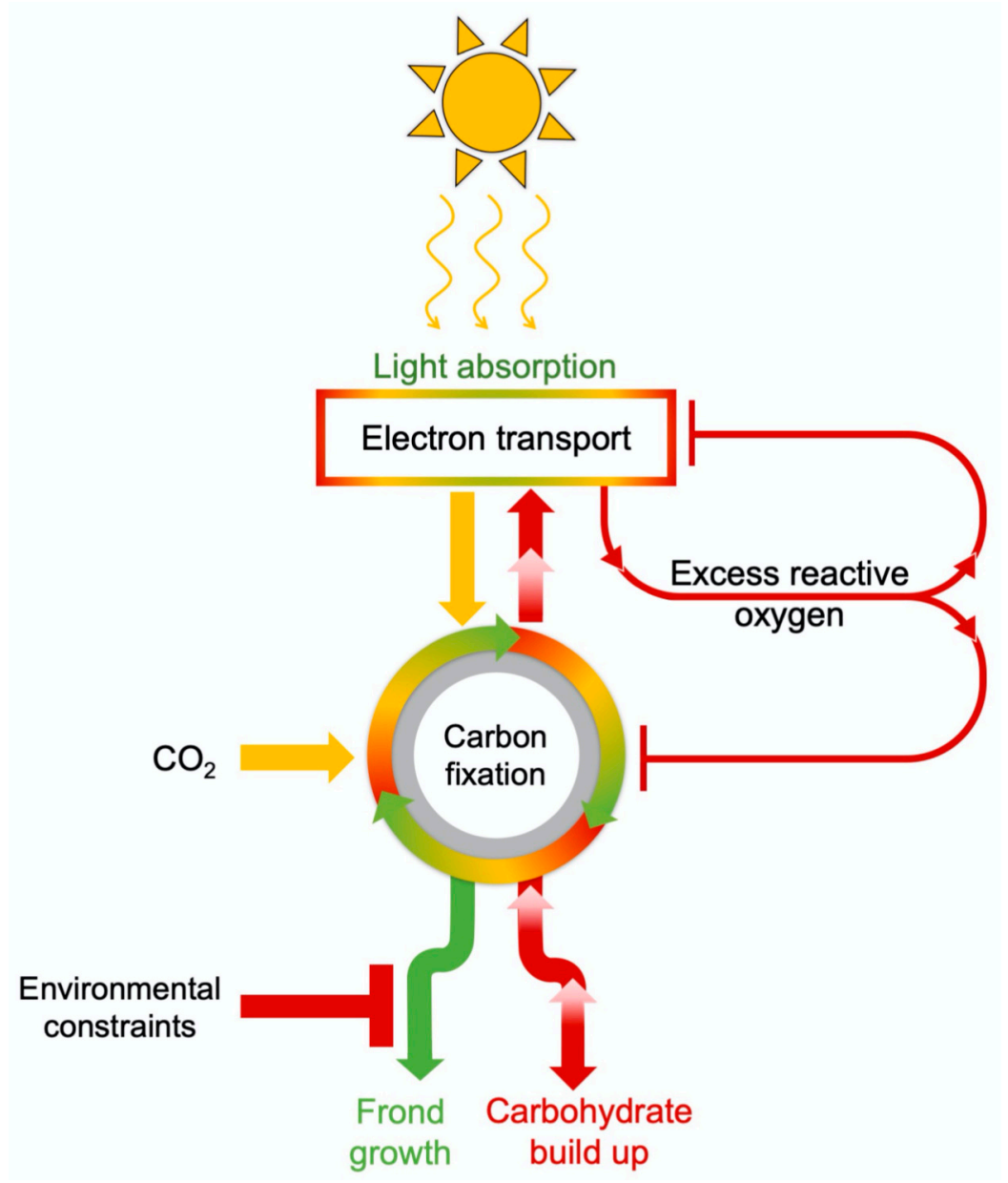

Figure 6. Schematic depiction of the effect of environmental inputs (light, $\mathrm{CO}_{2}$, and factors that limit leaf/frond growth) in triggering feedback inhibition of photosynthesis via repression of photosynthetic genes when carbohydrate builds up in leaves/fronds because of limiting sink activity.

\subsection{Comparative Evaluation of Plant Response to Light Supply}

Unlike most terrestrial plants, Lemna exhibited the same growth rate in low and high light (Figure 7; [24]), which can be viewed as an absence of growth reductions in low light or as an absence of growth reductions in highly excessive light. In the example of Figure 7, Lemna exhibited the same relative growth rate, measured as daily area expansion of new tissue, when grown under low light $\left(50 \mu \mathrm{mol}\right.$ photons $\left.\mathrm{m}^{-2} \mathrm{~s}^{-1}\right)$ as when grown with a $20 \times$ greater light supply $\left(1000 \mu \mathrm{mol}\right.$ photons $\left.\mathrm{m}^{-2} \mathrm{~s}^{-1}\right)$ for $24 \mathrm{~h}$ a day (Figure 7 ), which exceeds the total daily light supply on the longest, brightest day on earth. However, plants did accumulate more dry biomass (presumably carbohydrate) per frond area under the high light level. Likewise, Lemna aequinoctialis fronds growing under continuous light $(24 \mathrm{~h}$ photoperiod) accumulated more biomass than fronds growing under a $12 \mathrm{~h}$ photoperiod of an intermediate light intensity of $200 \mu \mathrm{mol}$ photons $\mathrm{m}^{-2} \mathrm{~s}^{-1}$ [67].

At the same time, Lemna did show some downregulation of maximal photosynthetic capacity (as a correlate of the number of photosynthetic enzymes) as well as pronounced downregulation of light-harvesting capacity (chlorophyll content) under the latter very high light supply (Figure 7; [24]). This downregulation can be viewed as economy on part of a $\mathrm{C}_{3}$ plant, whereby greater light exposure and more $\mathrm{CO}_{2}$ are able to support the same growth rate (area expansion) and more biomass accumulation with a lesser investment in proteins for light collection and $\mathrm{CO}_{2}$ fixation while releasing nitrogen from these photosynthetic proteins for use in area expansion [68]. A consequence of this downregulation is a lower nutritional quality in the form of a lower fraction of the accumulated biomass that consists of protein. The percentage of protein of dry biomass dropped from $46 \%$ in low light to 

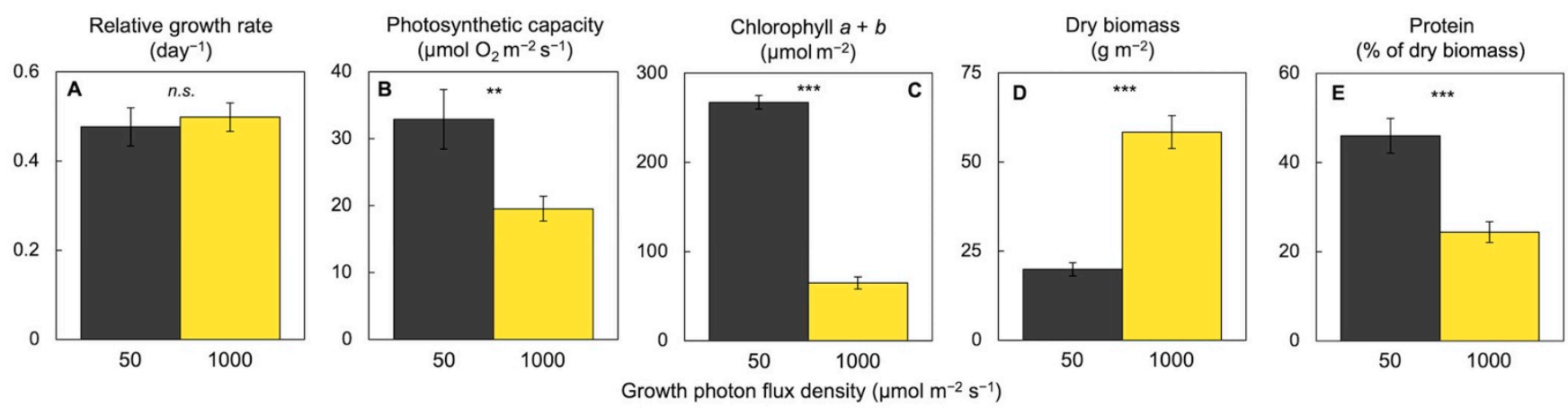

Figure 7. Effect of growth light intensity on (A) relative growth rate, (B) photosynthetic capacity, (C) chlorophyll content, and (D) biomass per frond area as well as (E) percentage of protein of this biomass for Lemna gibba. Data from [23]. n.s., not significant. Asterisks indicate significant differences at $\left.p<0.01{ }^{* *}\right)$ or $\left.p<0.001{ }^{* * *}\right)$.

Figures 8 and 9 illustrate responses of Lemna duckweed to a combination of high light and elevated $\mathrm{CO}_{2}$ with respect to a suite of similar features related to plant productivity, photosynthesis, and nutritional quality for the consumer. Under an extremely high $\mathrm{CO}_{2}$ level $(0.7 \%)$ in the presence of high light $\left(700 \mu \mathrm{mol}\right.$ photons $\mathrm{m}^{-2} \mathrm{~s}^{-1}$ for $24 \mathrm{~h}$ a day) and replete (sufficient) nutrient supply, duckweed grew new tissue at a relative growth rate of frond area expansion with a dry biomass content per area that were both similar under high versus ambient $\mathrm{CO}_{2}$ (Figure $8 \mathrm{~A}, \mathrm{~B}$ ). This finding is consistent with the high growth rate, i.e., high sink activity in the form of new tissue growth, of duckweed, and supports the notion that duckweed is remarkably insensitive to the adverse effects of $\mathrm{CO}_{2}$ on photosynthetic productivity. In contrast, there was-as expected-evidence for photosynthetic downregulation in the form of a somewhat lower photosynthetic capacity, much lower chlorophyll content, and much lower zeaxanthin content on a frond area basis (Figure 9) under high versus ambient $\mathrm{CO}_{2}$. These findings are consistent with the principle that the plant can support growth and biomass accumulation with less $\mathrm{CO}_{2}$-fixing protein in the presence of high $\mathrm{CO}_{2}$ levels. Photosynthetic downregulation targets not only the $\mathrm{CO}_{2}$-fixing enzymes but also several proteins involved in light collection and processing, including chlorophyll-binding proteins [60]. In turn, lower chlorophyll levels reduce light absorption and the need for the dissipation of excess excitation energy by zeaxanthin and other carotenoids. This downregulation of photosynthesis was thus associated with lower nutritional quality of the plant (Figures 8 and 9) in the form of a lower content of protein, zeaxanthin, lutein, and $\beta$-carotene (provitamin A). Lutein [70] and $\beta$-carotene [71] have additional roles in plant photoprotection and also act synergistically with zeaxanthin as membrane-soluble antioxidants that fight inflammation in humans [20-22]. 

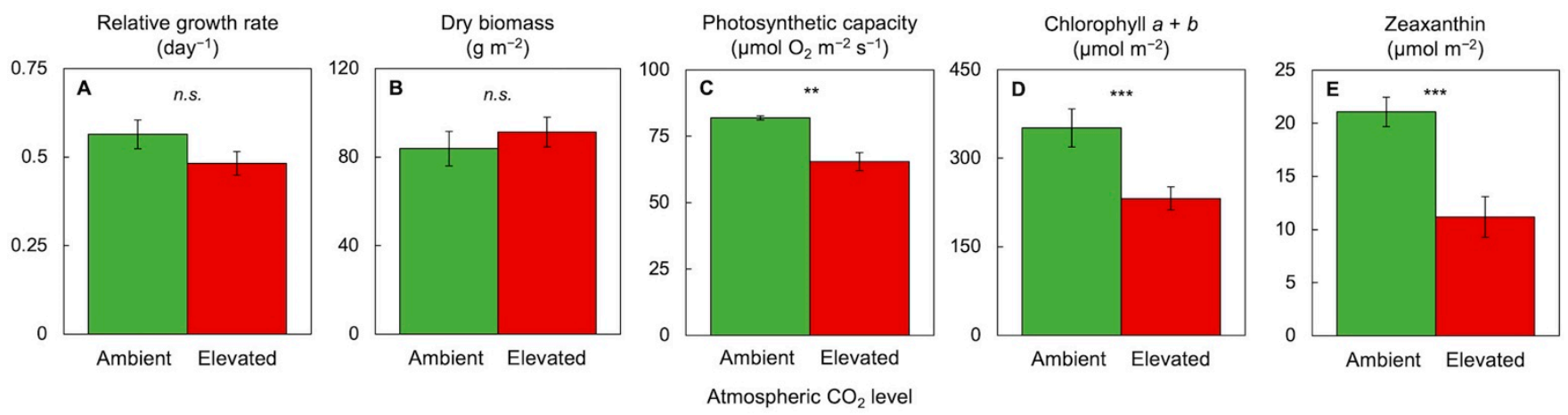

Figure 8. Effect of elevated compared to ambient atmospheric $\mathrm{CO}_{2}$ level on (A) the relative growth rate (of frond area expansion) as well as (B) dry biomass, (C) photosynthetic capacity, (D) chlorophyll content, and (E) zeaxanthin content per frond area in Lemna minor. Elevated $\mathrm{CO}_{2}$ level was $0.7 \%$; light environment was continuous light of $700 \mu \mathrm{mol}$ photons $\mathrm{m}^{-2} \mathrm{~s}^{-1}$; nutrient medium was $\frac{1}{2}$ strength Schenk and Hildebrandt medium [72]. For other experimental conditions and methods, see [23]. n.s., not significant. Asterisks indicate significant differences at $p<0.01\left(^{* *}\right)$ or $p<0.001\left(^{* * *}\right)$.
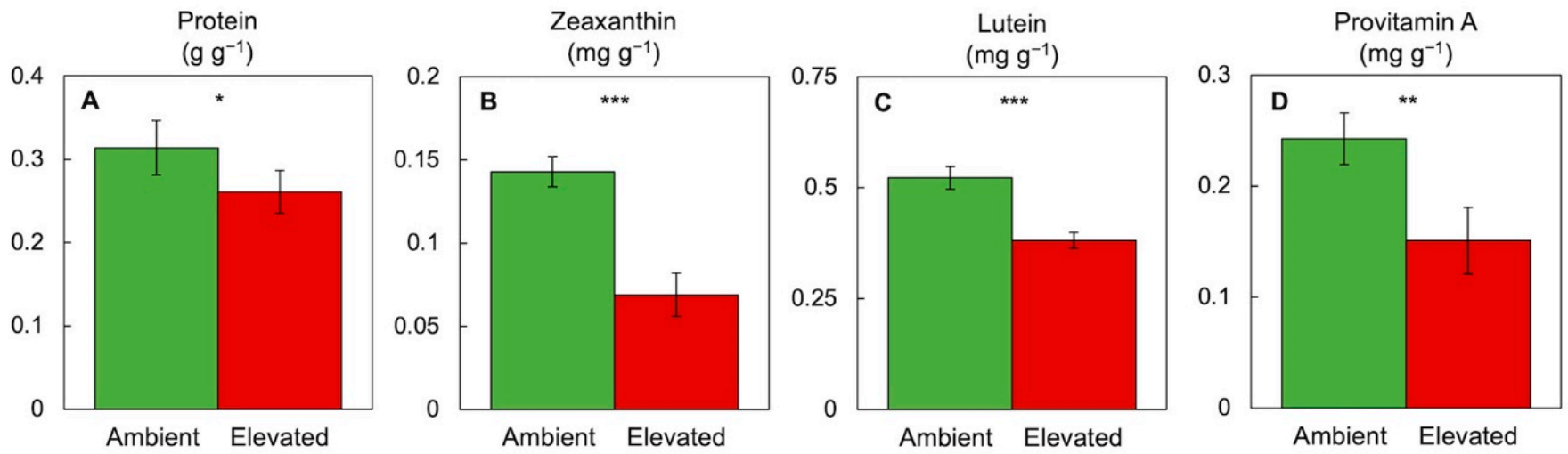

Atmospheric $\mathrm{CO}_{2}$ level

Figure 9. Effect of elevated compared to ambient atmospheric $\mathrm{CO}_{2}$ level on various human nutrients including (A) protein, (B) zeaxanthin, (C) lutein, and (D) provitamin A ( $\beta$-carotene) content per dry biomass in Lemna minor. $\mathrm{CO}_{2}$, light, and nutrient conditions were as listed in the legend of Figure 8. For protein quantification, see [24]. For all other experimental conditions and carotenoid quantification, see [23]. Asterisks indicate significant differences at $p<0.05\left({ }^{*}\right), p<0.01\left({ }^{* *}\right)$, or $p<0.001\left({ }^{* * *}\right)$.

While Lemna is thus susceptible to effects of high $\mathrm{CO}_{2}$ that are undesirable for the consumer, it exhibited no decline in the growth of new tissue under conditions of favorable nutrient supply. This relatively modest response to high light and $\mathrm{CO}_{2}$ supply may, once again, be associated with the low responsiveness of duckweeds' growth rate to environmental conditions. Furthermore, we saw no difference in plant response to $\mathrm{CO}_{2}$ over a wide range of $\mathrm{CO}_{2}$ levels from $0.086 \%(2 \times$ earth-ambient; not shown $)$ up to $0.7 \%$.

3.5. Comparative Evaluation of Plant Response to a Combination of High $\mathrm{CO}_{2}$, High Light Supply, and Limiting Mineral Nutrient Supply

Source-sink imbalance is further exacerbated by a combination of elevated $\mathrm{CO}_{2}$ and/or high light supply (which increase source strength) with additional environmental factors that decrease sink strength. An example of such an additional factor is a limited mineral nutrient supply $[29,73]$. The growth of sink tissues is highly sensitive to a shortage of mineral nutrients, especially nitrogen [74]. In terrestrial plants, the combination of elevated $\mathrm{CO}_{2}$ and/or high light supply with low nitrogen supply exacerbates source-sink imbalance and downregulates the synthesis of photosynthetic protein $[75,76]$, as well as other metabolic 
processes [61]. Growth under elevated $\mathrm{CO}_{2}$ can also lead to premature leaf senescence when sugars accumulate to levels that inhibit photosynthetic gene expression [77] (see also $[75,78-80])$. Both growth declines and accelerated senescence can be viewed in the context of sugar signals controlling plant progression through the life cycle [81]. Carbohydrate accumulation can be a signal that sufficient resources are available for flowering and completion of the life cycle, and such signals are generated earlier in a plant's life cycle when limited mineral nutrients enhance carbohydrate accumulation [81]. In fact, it was proposed that some level of nitrogen fertilization of nutrient-limited natural plant communities may mitigate the negative effects of elevated $\mathrm{CO}_{2}$ [82].

Duckweeds likewise respond with enhanced carbohydrate accumulation to a combination of high light supply and/or elevated $\mathrm{CO}_{2}$ coupled with low nutrient levels in the medium. Pronounced starch accumulation in fronds growing in a nutrient-deficient medium [83-85] was further exacerbated by extended photoperiods [86]. However, several traits of duckweeds may lessen the overall impact of such combinations of environmental factors. Duckweeds exhibit a higher tolerance than terrestrial plants to carbohydrate build-up and can accumulate [5] considerable starch levels before showing photosynthetic downregulation $[23,83,86,87]$. In terrestrial plants, a limited capacity for nitrogen uptake and utilization caused enhanced sink limitation $[66,88]$, whereas a high propensity for efficient nitrogen uptake alleviated sink limitation. Compared to terrestrial plants, Lemna exhibits highly efficient uptake $[89,90]$ and conversion of nitrogen to amino acids [91] and accumulates much larger quantities of protein in its fronds [4,83].

Effective nutrient uptake and the propensity to accumulate high protein levels allows duckweed to reclaim polluted waters $[6,8]$ and convert wastewater to high-quality animal feed $[5,7,9,92]$. The quantity of edible protein produced by duckweed per hectare of production area greatly exceeds that of soybean $[5,93]$ since duckweeds accumulate high levels of vegetative storage protein in their fronds $[4,93]$, whereas soybean accumulates high levels of protein only in its seeds, which represent a small fraction of the plant. Highly efficient nutrient uptake and accumulation of vegetative storage protein, resulting in exceptionally high plant protein contents, is also seen in other aquatic floating plants [94,95]. Many of these other aquatic plants are also edible; more than 70 wetland plants of India were identified as edible or medicinal plants by Swapna et al. ([38], e.g., ten species in the Asteraceae, six each in the Poaceae and Commelinaceae, and six in the order Alismatales, with four Araceae and two Hydrocharitaceae; see also [96]). From an ecological perspective, a combination of effective uptake and the storage of nitrogen as vegetative storage protein in aquatic environments may be advantageous in small- to mid-sized freshwater bodies that receive an intermittent influx of nutrients. Duckweeds were shown to continue growing in low-nutrient media for a certain amount of time by utilizing internal nutrient stocks [83]. Efficient nutrient uptake and storage, as vegetative protein, should enable the plants to take advantage of the pulses of nutrient availability in support of the continuous growth of new fronds until dense duckweed mats dramatically reduce the light available to algae and submerged aquatic plants that compete for nutrients. The properties shared by aquatic floating plants that set them apart from most terrestrial plants thus reflect adaptations to the unique aquatic environment with its inherent variability and opportunities.

3.6. Comparative Evaluation of Plant Response to Combinations of $\mathrm{High}^{\mathrm{CO}} \mathrm{O}_{2}$, High Light Supply, and High Mineral Nutrient Supply

Remarkably, high nitrate supply can also decrease photosynthetic rates of terrestrial plants, especially when combined with conditions that result in carbohydrate build-up, such as extended photoperiods [97] or elevated $\mathrm{CO}_{2}$ [98,99]. Under these conditions, excessive ROS production in the chloroplast is combined with the production of additional oxidants in other cell compartments that participate in nitrate metabolism. Specifically, a high activity of the nitrate-reducing enzyme nitrate reductase produces high levels of messengers (both ROS and reactive nitrogen species, RNS; [99]) that modulate nitrogen metabolism [100-102] and can also trigger plant senescence ([66,103]; see also [104,105]). 
Such findings led to a suggestion that "in a future environment with high $\mathrm{CO}_{2}$ levels the use of fertilizers containing low concentrations of nitrate could improve ... [nitrogen] assimilation" in terrestrial crops [106]. A similar warning and recommendations were issued by Bloom [107] in a communication entitled "As carbon dioxide rises, food quality will decline without careful nitrogen management." Ammonium metabolism does not have the same propensity as nitrate metabolism for the generation of ROS and RNS [108] and the resulting disruption of redox homeostasis. On the other hand, the accumulation of ammonium in plant tissue can disrupt cellular $\mathrm{pH}$ balance (and some other aspects of metabolism) in many terrestrial plants [109]. However, some plants, including those growing in marshes, are adept at using ammonium [107]. The preference of duckweeds (and other aquatic plants) for the uptake of ammonium over nitrate also has the potential to avoid high rates of nitrate reduction and its adverse effects, and duckweed's efficient conversion of ammonium to vegetative storage protein limits ammonium accumulation and resulting toxicity.

\section{Plant-Microbe Interaction and the Abiotic Environment}

Whereas adverse effects of high $\mathrm{CO}_{2}$ in the absence of nutrient deficiency or other abiotic stresses can presumably be mitigated by avoiding high light intensities or long photoperiods, the additional presence of unfavorable nutrient conditions will likely require other measures. Plant-microbe interaction may offer the mitigation of adverse effects of combinations of environmental factors that exacerbate the source-sink imbalance. The extent of plant response to the presence of microorganisms depends on environmental conditions [110] such as $\mathrm{CO}_{2}$ level (see, e.g., [111-114]) and nitrogen availability (see, e.g., $[115,116])$. Lemna minor exhibited a decline in growth rate, which was strongly exacerbated under elevated $\mathrm{CO}_{2}$ levels (twice-ambient), starting several days following the transfer from replete nutrient medium to very low nutrient levels in Schenk and Hildebrandt [72] medium diluted by a factor of $1 / 20$ [117].

While experimental manipulation of the plant microbiome is challenging in terrestrial plants growing in soil, some evidence is available for enhanced plant productivity in the presence of fungal partners of terrestrial plants [118,119]. Inoculation of terrestrial plant roots with arbuscular mycorrhizal fungi increased root volume and activity, triggering photosynthetic upregulation in some systems $[118,120]$. Conversely, the elimination of the mycorrhizal system of cucumber resulted in declining photosynthesis rates ([121]; see also [122]). Transcriptomic analysis of such systems revealed differential gene expression in pathways of photosynthesis, hormone metabolism, carbohydrate metabolism, amino acid metabolism, stress response, signal transduction, and antioxidation [119].

Legumes that feature symbioses with $\mathrm{N}_{2}$-fixing bacteria had greater photosynthesis rates under elevated $\mathrm{CO}_{2}$ and maintained higher protein content and higher overall ratios of nitrogen to carbon in their tissues [123]. In contrast, most non-leguminous $C_{3}$ crops exhibit increased carbon-to-nitrogen ratios under elevated atmospheric $\mathrm{CO}_{2}[124,125]$. Lemnaceae exhibit robust interaction with microorganisms [126-128], and duckweed photosynthesis rate as well as growth rate can be stimulated by the plant microbiome [127-132]. Whereas plant-microbe interaction can thus clearly benefit the plant, the existence of additional layers of complexity should be noted. Microorganisms may engage in competition with plants for mineral nutrients in certain environments; the same bacterial strains that strongly promoted duckweed growth under some conditions reduced plant growth under limiting levels of mineral nutrients other than nitrogen $[127,130,133]$. Duckweeds are an attractive model system for the study of plant-microbe interaction due to the ease of inoculation and manipulation of the rhizosphere as well as the fact that their small size and high growth rates favor multi-factorial design of growth experiments in different growth environments with plants fully acclimated to these conditions. Other aquatic floating plants also form alliances with microorganisms, especially potential $\mathrm{N}_{2}$-fixing clades (see, e.g., [134]).

An integrative review of literature on (i) plant performance under high $\mathrm{CO}_{2}$ and (ii) plant-microbe interaction and symbioses between photosynthetic and non-photosynthetic 
organisms [58] suggests that microorganisms can enhance plant photosynthetic productivity and nutritional quality (Figures 10 and 11) by (i) serving as an additional sugar sink that prevents carbohydrate build-up [130,132,135-138] and resulting excess ROS formation (see above), (ii) balancing nutrient supply (limiting or excess; see above) and producing growth factors [139], (iii) producing gene regulators that safely re-route electrons and, thereby, further counteract disruption of redox homeostasis under both limiting nutrient supply and very high nitrate supply (see, e.g., $[108,140]$ ). Alternative outlets for electrons include cyclic electron flow in the chloroplast [141-146]. Since mitochondria and cell membrane-associated processes also produce excess oxidants under elevated $\mathrm{CO}_{2}$ levels, the maintenance of cellular redox homeostasis [64] requires coordination of electron flow in chloroplasts and mitochondria. Plant-specific mitochondrial alternative oxidase (AOX) is a key player in this coordination [147-151] and serves as a safe outlet for electrons when environmental shifts threaten to disrupt metabolism $[147,152,153]$. Plant AOX levels increased in response to high $\mathrm{CO}_{2}$ and light supply $[147,148,154]$ as well as under limiting nitrogen [155]. Furthermore, the plant rhizosphere microbiome interacts with plant AOX [140].

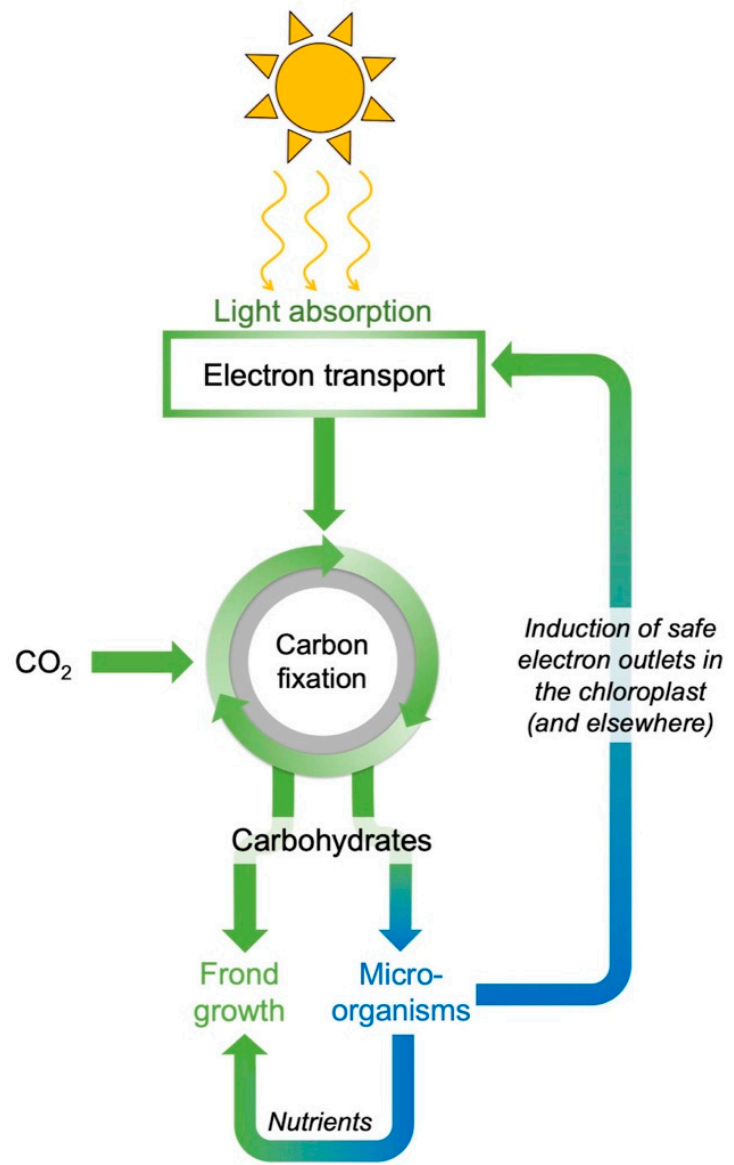

Figure 10. Schematic depiction of the effect of microorganisms in counteracting feedback inhibition of photosynthesis by (i) acting as a sink for carbohydrates, (ii) improving plant nitrogen content in support of new growth (as well as photosynthetic capacity), and (iii) indirectly and directly promoting safe electron outlets in chloroplasts and elsewhere. 


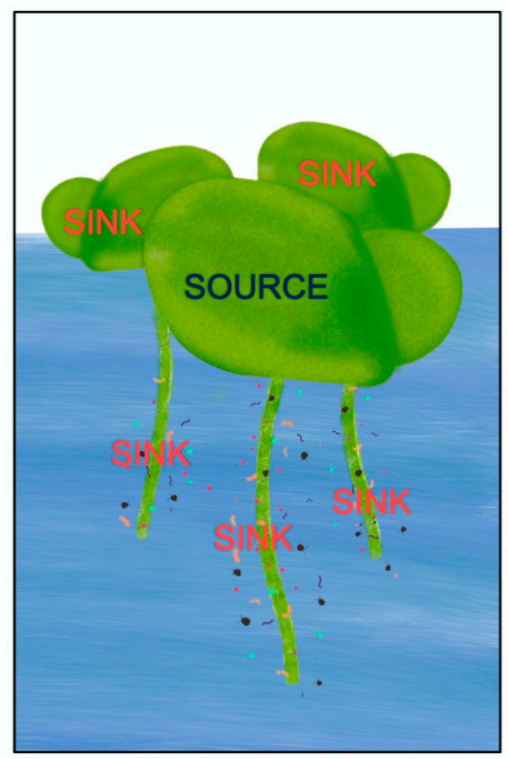

Figure 11. Schematic depiction of a Lemna colony consisting of a mother frond as the source of photosynthate for expanding daughter fronds as well as for the rhizosphere microbiome as sinks of photosynthate.

Plant-microbe interaction may thereby allow plants to take advantage of high light and $\mathrm{CO}_{2}$ for growth and biomass accumulation by maintaining a high photosynthetic capacity with high levels of photosynthetic protein, chlorophyll, and chlorophyll-protecting antioxidants. This suggestion is supported by recent findings that the inoculation of previously sanitized L. minor with pond water supporting populations of $L$. minor prevented the decline in relative growth rate seen upon transfer to $1 / 20$ strength Schenk and Hildebrandt medium in un-inoculated controls [117]. Moreover, inoculated fronds accumulated greater levels of dry biomass with the same ratio of protein to biomass as uninoculated fronds under either ambient or twice-ambient $\mathrm{CO}_{2}$ [117]. By supporting a sustained high photosynthetic capacity, microorganisms can thus favor the production of a steady stream of carbohydrate for consumption by both microorganisms and growing plant tissue and discourage metabolic imbalances that trigger photosynthetic downregulation and/or accelerated senescence.

\section{Conclusions}

The unique features of aquatic plants reflect adaptations to the freshwater environment and include rapid growth, high productivity, and strong accumulation of high-quality vegetative storage protein as well as essential human micronutrients. These micronutrients include carotenoids with wide-ranging roles in human health and a unique carotenoid composition of Lemna. Other aquatic plants may share this latter trait and should be further tested for edibility and nutritional quality. The relative insensitivity of duckweed's growth rate to environmental conditions and plant source-sink imbalance may allow duckweeds to take advantage of elevated atmospheric $\mathrm{CO}_{2}$ levels via particularly strong stimulation of biomass production and relative insensitivity to declines in the growth of new tissue. It may be possible to mitigate the declines in nutritional quality under elevated $\mathrm{CO}_{2}$ associated with regulatory adjustments in photosynthetic metabolism by plant-microbe interaction.

Author Contributions: Conceptualization, B.D.-A. and W.W.A.III; formal analysis, B.D.-A., W.W.A.III, M.L.-P., S.K.P. and J.J.S.; investigation, M.L.-P., W.W.A.III, J.J.S. and M.C.Z.; resources, B.D.-A. and W.W.A.III; writing - original draft preparation, B.D.-A., W.W.A.III and S.K.P.; writing-review and editing, J.J.S., M.L.-P., P.F. and M.C.Z.; visualization, B.D.-A., W.W.A.III, S.K.P. and J.J.S.; supervision and project administration, B.D.-A. and W.W.A.III; funding acquisition, B.D.-A., W.W.A.III and J.J.S. All authors have read and agreed to the published version of the manuscript. 
Funding: This work was funded by the Translational Research Institute for Space Health through Cooperative Agreement NNX16AO69A, the National Science Foundation award number IOS-1907338, and the University of Colorado.

\section{Institutional Review Board Statement: Not applicable.}

Informed Consent Statement: Not applicable.

Data Availability Statement: Data are contained within the article.

Acknowledgments: We thank Christine and Adam Escobar for many stimulating discussions about duckweeds and their essential contributions to starting the work on duckweed in our group, including building photodiode arrays for lighting and improving $\mathrm{CO}_{2}$ control of Conviron growth chambers. We thank Gabrielle Glime for assistance with lab maintenance.

Conflicts of Interest: The authors declare no conflict of interest.

\section{References}

1. Acosta, K.; Appenroth, K.J.; Borisjuk, L.; Edelman, M.; Heinig, U.; Jansen, M.A.K.; Oyama, T.; Pasaribu, B.; Schubert, I.; Sorrels, S.; et al. Return of the Lemnaceae: Duckweed as a model plant system in the genomics and postgenomics era. Plant Cell 2021, 33, 3207-3234. [CrossRef]

2. Sree, K.S.; Sudakaran, S.; Appenroth, K.-J. How fast can angiosperms grow? Species and clonal diversity of growth rates in the genus Wolffia (Lemnaceae). Acta Physiol. Plant. 2015, 37, 204. [CrossRef]

3. Ziegler, P.; Adelmann, K.; Zimmer, S.; Schmidt, C.; Appenroth, K.-J. Relative In Vitro growth rates of duckweeds (Lemnaceae)— The most rapidly growing higher plants. Plant Biol. 2015, 17, 33-41. [CrossRef]

4. $\quad$ Appenroth, K.-J.; Sree, K.S.; Böhm, V.; Hammann, S.; Vetter, W.; Leiterer, M.; Jahreis, G. Nutritional value of duckweeds (Lemnaceae) as human food. Food Chem. 2017, 217, 266-273. [CrossRef] [PubMed]

5. Skillicorn, P.; Spira, W.; Journey, W. Duckweed Aquaculture: A New Aquatic Farming System for Developing Countries; The World Bank: Washington, DC, USA, 1993.

6. Körner, S.; Vermaat, J.E. The relative importance of Lemna gibba L.; bacteria and algae for the nitrogen and phosphorus removal in duckweed-covered domestic wastewater. Water Res. 1998, 32, 3651-3661. [CrossRef]

7. $\mathrm{Xu}, \mathrm{J} . ;$ Shen, G. Effects of harvest regime and water depth on nutrient recovery from swine wastewater by growing Spirodela oligorrhiza. Water Environ. Res. 2011, 83, 2049-2056. [CrossRef]

8. Ekperusi, A.O.; Sikoki, F.D.; Nwachukwu, E.O. Application of common duckweed (Lemna minor) in phytoremediation of chemicals in the environment: State and future perspective. Chemosphere 2019, 223, 285-309. [CrossRef] [PubMed]

9. Roman, B.; Brennan, R.A. Coupling ecological wastewater treatment with the production of livestock feed and irrigation water provides net benefits to human health and the environment: A life cycle assessment. J. Environ. Manag. 2021, $288,112361$. [CrossRef] [PubMed]

10. Yao, Y.; Zhang, M.; Tian, Y.; Zhao, M.; Zhang, B.; Zhao, M.; Zeng, K.; Yin, B. Duckweed (Spirodela polyrhiza) as green manure for increasing yield and reducing nitrogen loss in rice production. Field Crops Res. 2017, 214, 273-282. [CrossRef]

11. Yuan, J.; Xu, K. Effects of simulated microgravity on the performance of the duckweeds Lemna aequinoctialis and Wolffia globosa. Aquat. Bot. 2017, 137, 65-71. [CrossRef]

12. Haynes, R.R.; Les, D.H. Alismatales (Water Plantains). In eLS; Wiley: Hoboken, NJ, USA, 2005. [CrossRef]

13. Ortiz, O.O.; Ibáñez, A.; Trujillo-Trujillo, E.; Croat, T.B. The emergent macrophyte Montrichardia linifera (Arruda) Schott (Alismatales: Araceae), a rekindled old friend from the Pacific Slope of lower Central America and western Colombia. Nord. J. Bot. 2020, 38, 1-10. [CrossRef]

14. Bonora, A.; Pancaldi, S.; Gualandri, R.; Fasulo, M.P. Carotenoid and ultrastructure variations is plastids of Arum italicum Miller fruit during maturation and ripening. J. Exp. Bot. 2000, 51, 873-884. [CrossRef] [PubMed]

15. Demmig-Adams, B.; Stewart, J.J.; Adams, W.W., III. Photoprotection and the trade-off between abiotic and biotic defense. In Non-Photochemical Quenching and Energy Dissipation in Plants, Advances in Photosynthesis and Respiration; Demmig-Adams, B., Garab, G., Adams, W.W., III, Govindjee, U., Eds.; Springer: Dordrecht, The Netherlands, 2014; Volume 40, pp. 631-643. [CrossRef]

16. Demmig-Adams, B.; Stewart, J.J.; López-Pozo, M.; Polutchko, S.K.; Adams, W.W., III. Zeaxanthin, a molecule for photoprotection in many different environments. Molecules 2020, 25, 5825. [CrossRef] [PubMed]

17. Demmig-Adams, B.; Ebbert, V.; Mellman, D.L.; Mueh, K.E.; Schaffer, L.; Funk, C.; Zarter, C.R.; Adamska, I.; Jansson, S.; Adams, W.W., III. Modulation of PsbS and flexible vs sustained energy dissipation by light environment in different species. Physiol. Plant. 2006, 127, 670-680. [CrossRef]

18. Demmig-Adams, B.; Adams, W.W., III; Barker, D.H.; Logan, B.A.; Verhoeven, A.S.; Bowling, D.R. Using chlorophyll fluorescence to assess the allocation of absorbed light to thermal dissipation of excess excitation. Physiol. Plant. 1996, 98, 253-264. [CrossRef]

19. Demmig-Adams, B.; Adams, W.W., III. Capacity for energy dissipation in the pigment bed in leaves with different xanthophyll cycle pools. Funct. Plant Biol. 1994, 21, 575-588. [CrossRef] 
20. Polutchko, S.K.; Stewart, J.J.; Demmig-Adams, B. Integrative view of the nutrition of the eye. In Nutraceuticals and Functional Foods in Human Health and Disease Prevention; Bagchi, D., Preuss, H.G., Swaroop, A., Eds.; CRC Press/Taylor \& Francis: Boca Raton, FL, USA, 2015; pp. 407-417. [CrossRef]

21. Demmig-Adams, B.; López-Pozo, M.; Stewart, J.J.; Adams, W.W., III. Zeaxanthin and lutein: Photoprotectors, anti-inflammatories, and brain food. Molecules 2020, 25, 3607. [CrossRef] [PubMed]

22. Polutchko, S.K.; Glime, G.N.E.; Demmig-Adams, B. Synergistic action of membrane-bound and water-soluble antioxidants in neuroprotection. Molecules 2021, 26, 5385. [CrossRef]

23. Stewart, J.J.; Adams, W.W., III; Escobar, C.M.; López-Pozo, M.; Demmig-Adams, B. Growth and essential carotenoid micronutrients in Lemna gibba as a function of growth light intensity. Front. Plant Sci. 2020, 11, 480. [CrossRef]

24. Stewart, J.J.; Adams, W.W., III; López-Pozo, M.; Doherty Garcia, N.; McNamara, M.; Escobar, C.M.; Demmig-Adams, B. Features of the duckweed Lemna that support rapid growth under extremes of light intensity. Cells 2021, 10, 1481. [CrossRef]

25. Demmig-Adams, B.; Adams, W.W. III. Carotenoid composition in sun and shade leaves of plants with different life forms. Plant Cell Environ. 1992, 15, 411-419. [CrossRef]

26. Zarter, C.R.; Adams, W.W., III; Ebbert, V.; Adamska, I.; Jansson, S.; Demmig-Adams, B. Winter acclimation of PsbS and related proteins in the evergreen Arctostaphylos uva-ursi as influenced by altitude and light environment. Plant Cell Environ. 2006, 29, 869-878. [CrossRef]

27. Zarter, C.R.; Adams, W.W., III; Ebbert, V.; Cuthbertson, D.J.; Adamska, I.; Demmig-Adams, B. Winter down-regulation of intrinsic photosynthetic capacity coupled with up-regulation of Elip-like proteins and persistent energy dissipation in a subalpine forest New Phytol. 2006, 172, 272-282. [CrossRef]

28. Verhoeven, A.S.; Demmig-Adams, B.; Adams, W.W., III. Enhanced employment of the xanthophyll cycle and thermal energy dissipation in spinach exposed to high light and N stress. Plant Physiol. 1997, 113, 817-824. [CrossRef]

29. Logan, B.A.; Demmig-Adams, B.; Rosenstiel, T.N.; Adams, W.W., III. Effect of nitrogen limitation on foliar antioxidants in relationship to other metabolic characteristics. Planta 1999, 209, 213-220. [CrossRef]

30. Demmig-Adams, B.; Stewart, J.J.; Adams, W.W., III. Environmental regulation of intrinsic photosynthetic capacity: An integrated view. Curr. Opin. Plant Biol. 2017, 37, 34-41. [CrossRef] [PubMed]

31. Terashima, I. Productive structure of a leaf. In Photosynthesis; Briggs, W.R., Ed.; Alan R. Liss: New York, NY, USA, 1989; pp. 207-226.

32. Adams, W.W., III; Demmig-Adams, B.; Barker, D.H.; Kiley, S. Carotenoids and photosystem II characteristics of upper and lower halves of leaves acclimated to high light. Aust. J. Plant Physiol. 1996, 23, 669-677. [CrossRef]

33. Havaux, M.; Niyogi, K.K. The violaxanthin cycle protects plants from photooxidative damage by more than one mechanism. Proc. Natl. Acad. Sci. USA 1999, 96, 8762-8767. [CrossRef]

34. Havaux, M.; García-Plazaola, J.I. Beyond non-photochemical fluorescence quenching: The overlapping antioxidant functions of zeaxanthin and tocopherols. In Non-Photochemical Quenching and Energy Dissipation in Plants, Advances in Photosynthesis and Respiration; Demmig-Adams, B., Garab, G., Adams, W.W., III, Govindjee, U., Eds.; Springer: Dordrecht, The Netherlands, 2014; Volume 40, pp. 583-603. [CrossRef]

35. Nilkens, M.; Kress, E.; Lambrev, P.; Miloslavina, Y.; Müller, M.; Holzwarth, A.R.; Jahns, P. Identification of a slowly inducible zeaxanthin-dependent component of non-photochemical quenching of chlorophyll fluorescence generated under steady-state conditions in Arabidopsis. Biochim. Biophys. Acta 2010, 1797, 466-475. [CrossRef] [PubMed]

36. Muztar, J.A.; Slinger, S.J.; Burton, J.H. Chemical composition of aquatic macrophytes I. Investigation of organic constituents and nutritional potential. Can. J. Plant Sci. 1978, 58, 829-841. [CrossRef]

37. Rice, S.K. Patterns of allocation and growth in aquatic Sphagnum species. Can. J. Bot. 1995, 73, 349-359. [CrossRef]

38. Swapna, M.M.; Prakashkumar, R.; Anoop, K.P.; Manju, C.N.; Rajith, N.P. A review on the medicinal and edible aspects of aquatic and wetland plants of India. J. Med. Plant Res. 2011, 5, 7163-7176. [CrossRef]

39. Huang, M.; Shan, S.; Zhou, X.; Chen, J.; Cao, F.; Jiang, L.; Zou, Y. Leaf photosynthetic performance related to higher radiation use efficiency and grain yield in hybrid rice. Field Crops Res. 2016, 193, 87-93. [CrossRef]

40. Garbulsky, M.F.; Peñuelas, J.; Gamon, J.; Inoue, Y.; Filella, I. The photochemical reflectance index (PRI) and the remote sensing of leaf, canopy and ecosystem radiation use efficiencies: A review and meta-analysis. Remote Sens. Environ. 2011, 115, 281-297. [CrossRef]

41. Porcar-Castell, A.; Tyystjärvi, E.; Atherton, J.; van der Tol, C.; Flexas, J.; Pfündel, E.E.; Moreno, J.; Frankenberg, C.; Berry, J.A. Linking chlorophyll a fluorescence to photosynthesis for remote sensing applications: Mechanisms and challenges. J. Exp. Bot. 2014, 65, 4065-4095. [CrossRef]

42. Thouvenot, L.; Haury, J.; Thiebaut, G. A success story: Water primroses, aquatic plant pests. Aquat. Conserv. Mar. Freshw. Ecosyst. 2013, 23, 790-803. [CrossRef]

43. Chen, F.; Liu, X.; Yu, C.; Chen, Y.; Tang, H.; Zhang, L. Water lilies as emerging models for Darwin's abominable mystery. Hortic. Res. 2017, 4, 17051. [CrossRef]

44. Michael, T.P.; Ernst, E.; Hartwick, N.; Chu, P.; Bryant, D.; Gilbert, S.; Ortleb, S.; Baggs, E.L.; Sree, K.S.; Appenroth, K.J.; et al. Genome and time-of-day transcriptome of Wolffia australiana link morphological minimization with gene loss and less growth control. Genome Res. 2021, 31, 225-238. [CrossRef]

45. Hsiao, T.C. Plant responses to water stress. Annu. Rev. Plant Physiol. 1973, 24, 519-570. [CrossRef] 
46. Dolferus, R. To grow or not to grow: A stressful decision for plants. Plant Sci. 2014, 229, 247-261. [CrossRef]

47. Patten, D.T. Productivity and production efficiency of an upper Sonoran Desert ephemeral community. Am. J. Bot. 1978, 65, 891-895. [CrossRef]

48. Parray, J.A.; Mir, M.Y.; Shameem, N. Stress management: Sustainable approach towards resilient agriculture. In Sustainable Agriculture: Biotechniques in Plant Biology; Parray, J.A., Mir, M.Y., Shameem, N., Eds.; Springer: Singapore, 2019; pp. 231-270. [CrossRef]

49. Beena, R.; Kirubakaran, S.; Nithya, N.; Manickavelu, A.; Sah, R.P.; Abida, P.S.; Sreekumar, J.; Jaslam, P.M.; Rejeth, R.; Jayalekshmy, V.G.; et al. Association mapping of drought tolerance and agronomic traits in rice (Oryza sativa L.) landraces. BMC Plant Biol. 2021, 21, 484. [CrossRef] [PubMed]

50. Nilsen, E.T.; Sharifi, M.R.; Rundel, P.W.; Jarrell, W.M.; Virginia, R.A. Diurnal and seasonal water relations of the desert phreatophyte Prosopis glandulosa (honey mesquite) in the Sonoran Desert of California. Ecology 1983, 64, 1381-1393. [CrossRef]

51. Nilsen, E.T.; Sharifi, M.R.; Rundel, P.W. Comparative water relations of phreatophytes in the Sonoran Desert of California. Ecology 1984, 65, 767-778. [CrossRef]

52. Sala, A.; Smith, S.D.; Devitt, D.A. Water use by Tamarix ramosissima and associated phreatophytes in a Mojave Desert floodplain. Ecol. Appl. 1996, 6, 888-898. [CrossRef]

53. Hultine, K.R.; Williams, D.G.; Burgess, S.S.O.; Keefer, T.O. Contrasting patterns of hydraulic redistribution in three desert phreatophytes. Oecologia 2003, 135, 167-175. [CrossRef]

54. Hultine, K.R.; Koepke, D.F.; Pockman, W.T.; Fravolini, A.; Sperry, J.S.; Williams, D.G. Influence of soil texture on hydraulic properties and water relations of a dominant warm-desert phreatophyte. Tree Physiol. 2006, 26, 313-323. [CrossRef]

55. Guo, J.S.; Gear, L.; Hultine, K.R.; Koch, G.W.; Ogle, K. Non-structural carbohydrate dynamics associated with antecedent stem water potential and air temperature in a dominant desert shrub. Plant Cell Environ. 2020, 43, 1467-1483. [CrossRef]

56. Carvajal, D.E.; Loayza, A.P.; Rios, R.S.; Gianoli, E.; Squeo, F.A. Population variation in drought-resistance strategies in a desert shrub along an aridity gradient: Interplay between phenotypic plasticity and ecotypic differentiation. Perspect. Plant Ecol. Evol. Syst. 2017, 29, 12-19. [CrossRef]

57. Myers, S.S.; Zanobetti, A.; Kloog, I.; Huybers, P.; Leakey, A.D.B.; Bloom, A.J.; Carlisle, E.; Dietterich, L.H.; Fitzgerald, G.; Hasegawa, T.; et al. Increasing $\mathrm{CO}_{2}$ threatens human nutrition. Nature 2014, 510, 139-142. [CrossRef]

58. Demmig-Adams, B.; Polutchko, S.K.; Zenir, M.C.; Fourounjian, P.; Stewart, J.J.; López-Pozo, M.; Adams, W.W., III. Intersections: Photosynthesis, abiotic stress, and the plant microbiome. Photosynthetica, 2022; in press.

59. Körner, C. Paradigm shift in plant growth control. Curr. Opin. Plant Biol. 2015, 25, 107-114. [CrossRef]

60. Krapp, A.; Stitt, M. An evaluation of direct and indirect mechanisms for the "sink-regulation" of photosynthesis in spinach: Changes in gas exchange, carbohydrates, metabolites, enzyme activities and steady-state transcript levels after cold-girdling source leaves. Planta 1995, 195, 313-323. [CrossRef]

61. Tausz-Posch, S.; Tausz, M.; Bourgault, M. Elevated $\left[\mathrm{CO}_{2}\right]$ effects on crops: Advances in understanding acclimation, nitrogen dynamics and interactions with drought and other organisms. Plant Biol. 2020, 22, 38-51. [CrossRef]

62. Huang, H.; Ullah, F.; Zhou, D.X.; Yi, M.; Zhao, Y. Mechanisms of ROS regulation of plant development and stress responses. Front. Plant Sci. 2019, 10, 800. [CrossRef]

63. Foyer, C.H.; Noctor, G. Stress-triggered redox signalling: What's in pROSpect? Plant Cell Environ. 2016, 39, 951-964. [CrossRef]

64. Foyer, C.H.; Noctor, G. Redox homeostasis and signaling in a higher-CO 2 world. Annu. Rev. Plant Biol. 2020, 71, 157-182. [CrossRef] [PubMed]

65. Hasanuzzaman, M.; Bhuyan, M.H.M.B.; Parvin, K.; Bhuiyan, T.F.; Anee, T.I.; Nahar, K.; Hossen, M.S.; Zulfiqar, F.; Alam, M.M.; Fujita, M. Regulation of ros metabolism in plants under environmental stress: A review of recent experimental evidence. Int. J. Mol. Sci. 2020, 21, 8695. [CrossRef] [PubMed]

66. Padhan, B.K.; Sathee, L.; Meena, H.S.; Adavi, S.B.; Jha, S.K.; Chinnusamy, V. $\mathrm{CO}_{2}$ Elevation accelerates phenology and alters carbon/nitrogen metabolism vis-à-vis ROS abundance in bread wheat. Front. Plant Sci. 2020, 11, 1061. [CrossRef]

67. Yin, Y.; Yu, C.; Yu, L.; Zhao, J.; Sun, C.; Ma, Y.; Zhou, G. The influence of light intensity and photoperiod on duckweed biomass and starch accumulation for bioethanol production. Bioresour. Technol. 2015, 187, 84-90. [CrossRef] [PubMed]

68. Paul, M.J.; Foyer, C.H. Sink regulation of photosynthesis. J. Exp. Bot. 2001, 52, 1383-1400. [CrossRef] [PubMed]

69. Martindale, W.; Bowes, G. The effects of irradiance and $\mathrm{CO}_{2}$ on the activity and activation of ribulose-1,5-bisphosphate carboxylase/oxygenase in the aquatic plant Spirodela polyrhiza. J. Exp. Bot. 1996, 47, 781-784. [CrossRef]

70. Dall'Osto, L.; Lico, C.; Alric, J.; Giuliano, G.; Havaux, M.; Bassi, R. Lutein is needed for efficient chlorophyll triplet quenching in the major LHCII antenna complex of higher plants and effective photoprotection in vivo under strong light. BMC Plant Biol. 2006, 6, 32. [CrossRef] [PubMed]

71. Telfer, A. Singlet oxygen production by PSII under light stress: Mechanism, detection and the protective role of $\beta$-carotene. Plant Cell Physiol. 2014, 55, 1216-1223. [CrossRef] [PubMed]

72. Schenk, R.U.; Hildebrandt, A.C. Medium and techniques for induction and growth of monocotyledonous and dicotyledonous plant cell cultures. Can. J. Bot. 1972, 50, 199-204. [CrossRef]

73. Paul, M.J.; Driscoll, S.P. Sugar repression of photosynthesis: The role of carbohydrates in signalling nitrogen deficiency through source:sink imbalance. Plant Cell Environ. 1997, 20, 110-116. [CrossRef] 
74. Burnett, A.C.; Rogers, A.; Rees, M.; Osborne, C.P. Nutrient sink limitation constrains growth in two barley species with contrasting growth strategies. Plant Direct 2018, 2, e00094. [CrossRef]

75. Moore, B.D.; Cheng, S.; Sims, D.; Seemann, J.R. The biochemical and molecular basis for photosynthetic acclimation to elevated atmospheric $\mathrm{CO}_{2}$. Plant Cell Environ. 1999, 22, 567-582. [CrossRef]

76. Ainsworth, E.A.; Long, S.P. 30 years of free-air carbon dioxide enrichment (FACE): What have we learned about future crop productivity and its potential for adaptation? Glob. Chang. Biol. 2005, 27, 27-49. [CrossRef]

77. Prins, A.; Kunert, K.; Foyer, C.H. Atmospheric $\mathrm{CO}_{2}$ signalling, cellular redox state and plant growth and development. In Redox Metabolism and Longevity Relationships in Animals and Plants; Foyer, C.H., Faragher, R., Thornalley, P., Eds.; Taylor \& Francis: London, UK, 2008; Volume 62, pp. 229-252. [CrossRef]

78. Dai, N.; Schaffer, A.; Petreikov, M.; Shahak, Y.; Giller, Y.; Ratner, K.; Levine, A.; Granot, D. Overexpression of Arabidopsis hexokinase in tomato plants inhibits growth, reduces photosynthesis, and induces rapid senescence. Plant Cell 1999, 11, 1253-1266. [CrossRef]

79. Diaz, C.; Purdy, S.; Christ, A.; Morot-Gaudry, J.-F.; Wingler, A.; Masclaux-Daubresse, C. Characterization of markers to determine the extent and variability of leaf senescence in Arabidopsis. A metabolic profiling approach. Plant Physiol. 2005, 138, 898-908. [CrossRef]

80. Agüera, E.; De la Haba, P. Leaf senescence in response to elevated atmospheric $\mathrm{CO}_{2}$ concentration and low nitrogen supply. Biol. Plant. 2018, 62, 401-408. [CrossRef]

81. Wingler, A.; Purdy, S.; MacLean, J.A.; Pourtau, N. The role of sugars in integrating environmental signals during the regulation of leaf senescence. J. Exp. Bot. 2005, 57, 391-399. [CrossRef]

82. Wang, S.; Zhang, Y.; Ju, W.; Chen, J.M.; Ciais, P.; Cescatti, A.; Sardans, J.; Janssens, I.A.; Wu, M.; Berry, J.A.; et al. Recent global decline of $\mathrm{CO}_{2}$ fertilization effects on vegetation photosynthesis. Science 2020, 370, 1295-1300. [CrossRef] [PubMed]

83. Cheng, J.J.; Stomp, A.-M. Growing duckweed to recover nutrients from wastewaters and for production of fuel ethanol and animal feed. Clean Soil Air Water 2009, 37, 17-26. [CrossRef]

84. Xu, J.; Zhao, H.; Stomp, A.-M.; Cheng, J.J. The production of duckweed as a source of biofuels. Biofuels 2012, 3, 589-601. [CrossRef]

85. Tao, X.; Fang, Y.; Xiao, Y.; Jin, Y.L.; Ma, X.R.; Zhao, Y.; He, K.Z.; Zhao, H.; Wang, H.Y. Comparative transcriptome analysis to investigate the high starch accumulation of duckweed (Landoltia punctata) under nutrient starvation. Biotechnol. Biofuels 2013, 6, 72. [CrossRef]

86. Liu, Y.; Wang, X.; Fang, Y.; Huang, M.; Chen, X.; Zhang, Y.; Zhao, H. The effects of photoperiod and nutrition on duckweed (Landoltia punctata) growth and starch accumulation. Ind. Crops Prod. 2018, 115, 243-249. [CrossRef]

87. Appenroth, K.-J.; Sree, K.S.; Fakhoorian, T.; Lam, E. Resurgence of duckweed research and applications: Report from the 3rd International Duckweed Conference. Plant Mol. Biol. 2015, 89, 647-654. [CrossRef]

88. Adavi, S.B.; Sathee, L. Elevated $\mathrm{CO}_{2}$ differentially regulates root nitrate transporter kinetics in a genotype and nitrate dosedependent manner. Plant Sci. 2021, 305, 110807. [CrossRef] [PubMed]

89. Cedergreen, N.; Madsen, T.V. Nitrogen uptake by the floating macrophyte Lemna minor. New Phytol. 2002, 155, 285-292. [CrossRef]

90. Cedergreen, N.; Madsen, T.V. Light regulation of root and leaf $\mathrm{NO}_{3}$ - uptake and reduction in the floating macrophyte Lemna minor. New Phytol. 2004, 161, 449-457. [CrossRef]

91. Yu, C.; Zhao, X.; Qi, G.; Bai, Z.; Wang, Y.; Wang, S.; Ma, Y.; Liu, Q.; Hu, R.; Zhou, G. Integrated analysis of transcriptome and metabolites reveals an essential role of metabolic flux in starch accumulation under nitrogen starvation in duckweed. Biotechnol. Biofuels 2017, 10, 167. [CrossRef]

92. Zhao, Z.; Shi, H.; Liu, Y.; Zhao, H.; Su, H.; Wang, M.; Zhao, Y. The influence of duckweed species diversity on biomass productivity and nutrient removal efficiency in swine wastewater, Bioresour. Technol. 2014, 167, 383-389. [CrossRef]

93. Mohedano, R.A.; Costa, R.H.R.; Tavares, F.A.; Belli Filho, P. High nutrient removal rate from swine wastes and protein biomass production by full-scale duckweed ponds. Bioresour. Technol. 2012, 112, 98-104. [CrossRef] [PubMed]

94. Boyd, C.E. Fresh-water plants: A potential source of protein. Econ. Bot. 1968, 22, 359-368. [CrossRef]

95. Dewanji, A.; Chanda, S.; Si, L.; Barik, S.; Matai, S. Extractability and nutritional value of leaf protein from tropical aquatic plants. Plant Foods Hum. Nutr. 1997, 50, 349-357. [CrossRef]

96. Rai, U.N.; Sinha, S. Distribution of metals in aquatic edible plants: Trapa natans (Roxb.) Makino and Ipomoea aquatica Forsk. Environ. Monit. Assess. 2001, 70, 241-252. [CrossRef]

97. Zeng, J.; Sheng, H.; Liu, Y.; Wang, Y.; Wang, Y.; Kang, H.; Fan, X.; Sha, L.; Yuan, S.; Zhou, Y. High nitrogen supply induces physiological responsiveness to long photoperiod in barley. Front. Plant Sci. 2017, 8, 569. [CrossRef] [PubMed]

98. Du, S.; Zhang, Y.; Lin, X.; Wang, Y.; Tang, C. Regulation of nitrate reductase by nitric oxide in Chinese cabbage pakchoi (Brassica chinensis L.). Plant Cell Environ. 2008, 31, 195-204. [CrossRef]

99. Bian, Z.; Wang, Y.; Zhang, X.; Li, T.; Grundy, S.; Yang, Q.; Cheng, R. A review of environment effects on nitrate accumulation in leafy vegetables grown in controlled environments. Foods 2020, 9, 732. [CrossRef]

100. Shin, R.; Schachtman, D.P. Hydrogen peroxide mediates plant root cell response to nutrient deprivation. Proc. Natl. Acad. Sci. USA 2004, 101, 8827-8832. [CrossRef]

101. Kim, M.J.; Ciani, S.; Schachtman, D.P. A peroxidase contributes to ros production during Arabidopsis root response to potassium deficiency. Mol. Plant 2010, 3, 420-427. [CrossRef] 
102. Wu, F.; Sun, X.; Hu, X.; Zou, B.; Lin, N.; Lin, J.; Ji, K. Response of nitrogen metabolism in masson pine needles to elevated $\mathrm{CO}_{2}$. Forests 2020, 11, 390. [CrossRef]

103. Adavi, S.B.; Sathee, L. Elevated $\mathrm{CO}_{2}$ alters tissue balance of nitrogen metabolism and downregulates nitrogen assimilation and signalling gene expression in wheat seedlings receiving high nitrate supply. Protoplasma 2020, 258, 219-233. [CrossRef] [PubMed]

104. Queval, G.; Issakidis-Bourguet, E.; Hoeberichts, F.A.; Vandorpe, M.; Gakière, B.; Vanacker, H.; Miginiac-Maslow, M.; Van Breusegem, F.; Noctor, G. Conditional oxidative stress responses in the Arabidopsis photorespiratory mutant cat2 demonstrate that redox state is a key modulator of daylength-dependent gene expression, and define photoperiod as a crucial factor in the regulation of $\mathrm{H}_{2} \mathrm{O}_{2}$-induced cell death. Plant J. 2007, 52, 640-657. [CrossRef] [PubMed]

105. Krasensky-Wrzaczek, J.; Kangasjärvi, J. The role of reactive oxygen species in the integration of temperature and light signals. J. Exp. Bot. 2018, 69, 3347-3358. [CrossRef] [PubMed]

106. Begara-Morales, J.C. Nitric oxide signalling in a $\mathrm{CO}_{2}$-enriched environment. J. Exp. Bot. 2016, 67, 560-561. [CrossRef] [PubMed]

107. Bloom, A.J. As carbon dioxide rises, food quality will decline without careful nitrogen management. Calif. Agric. 2009, 63, 67-72. [CrossRef]

108. de Sousa Leite, T.; Monteiro, F.A. Partial replacement of nitrate by ammonium increases photosynthesis and reduces oxidative stress in tanzania guinea grass exposed to cadmium. Ecotoxicol. Environ. Saf. 2019, 174, 592-600. [CrossRef]

109. Britto, D.T.; Kronzucker, H.J. $\mathrm{NH}_{4}{ }^{+}$toxicity in higher plants: A critical review. J. Plant Physiol. 2002, 159, 567-584. [CrossRef]

110. Becklin, K.M.; Mullinix, G.W.R.; Ward, J.K. Host plant physiology and mycorrhizal functioning shift across a glacial through future $\left[\mathrm{CO}_{2}\right]$ gradient. Plant Physiol. 2016, 172, 789-801. [CrossRef]

111. Syvertsen, J.P.; Graham, J.H. Phosphorus supply and arbuscular mycorrhizas increase growth and net gas exchange responses of two Citrus spp. grown at elevated $\left[\mathrm{CO}_{2}\right.$ ]. Plant Soil 1999, 208, 209-219. [CrossRef]

112. Gavito, M.E.; Bruhn, D.; Jakobsen, I. Phosphorus uptake by arbuscular mycorrhizal hyphae does not increase when the host plant grows under atmospheric $\mathrm{CO}_{2}$ enrichment. New Phytol. 2002, 154, 751-760. [CrossRef]

113. Jifon, J.L.; Wolfe, D.W. Photosynthetic acclimation to elevated $\mathrm{CO}_{2}$ in Phaseolus vulgaris L. is altered by growth response to nitrogen supply. Glob. Chang. Biol. 2002, 8, 1018-1027. [CrossRef]

114. Nie, M.; Bell, C.; Wallenstein, M.D.; Pendall, E. Increased plant productivity and decreased microbial respiratory C loss by plant growth-promoting rhizobacteria under elevated $\mathrm{CO}_{2}$. Sci. Rep. 2015, 5, 9212. [CrossRef] [PubMed]

115. Johnson, N.C.; Wilson, G.W.T.; Bowker, M.A.; Wilson, J.A.; Miller, R.M. Resource limitation is a driver of local adaptation in mycorrhizal symbioses. Proc. Natl. Acad. Sci. USA 2010, 107, 2093-2098. [CrossRef]

116. Weese, D.J.; Heath, K.D.; Dentinger, B.T.M.; Lau, J.A. Long-term nitrogen addition causes the evolution of less-cooperative mutualists. Evolution 2015, 69, 631-642. [CrossRef]

117. Zenir, M. Productivity and Nutritional Quality of Lemna minor in Different Physical and Biological Environments. Senior Honors Thesis, University of Colorado Boulder, Boulder, CO, USA, 2021.

118. Romero-Munar, A.; Del-Saz, N.F.; Ribas-Carbó, M.; Flexas, J.; Baraza, E.; Florez-Sarasa, I.; Fernie, A.R.; Gulías, J. Arbuscular mycorrhizal symbiosis with Arundo donax decreases root respiration and increases both photosynthesis and plant biomass accumulation. Plant Cell Environ. 2017, 40, 1115-1126. [CrossRef] [PubMed]

119. Yang, Y.; Guo, Y.; Zhong, J.; Zhang, T.; Li, D.; Ba, T.; Xu, T.; Chang, L.; Zhang, Q.; Sun, M. Root physiological traits and transcriptome analyses reveal that root zone water retention confers drought tolerance to Opisthopappus taihangensis. Sci. Rep. 2020, 10, 2627. [CrossRef]

120. Chen, J.; Zhang, H.; Zhang, X.; Tang, M. Arbuscular mycorrhizal symbiosis alleviates salt stress in black locust through improved photosynthesis, water status, and $\mathrm{K}^{+} / \mathrm{Na}^{+}$homeostasis. Front. Plant Sci. 2017, 8, 1739. [CrossRef]

121. Gavito, M.E.; Jakobsen, I.; Mikkelsen, T.N.; Mora, F. Direct evidence for modulation of photosynthesis by an arbuscular mycorrhiza-induced carbon sink strength. New Phytol. 2019, 223, 896-907. [CrossRef]

122. Lamhamedi, M.S.; Godbout, C.; Fortin, J.A. Dependence of Laccariabicolor basidiome development on current photosynthesis of Pinusstrobus seedlings. Can. J. For. Res. 1994, 24, 1797-1804. [CrossRef]

123. Rogers, A.; Ainsworth, E.A.; Leakey, A.D.B. Will elevated carbon dioxide concentration amplify the benefits of nitrogen fixation in legumes? Plant Physiol. 2009, 151, 1009-1016. [CrossRef] [PubMed]

124. Leakey, A.D.B.; Ainsworth, E.A.; Bernacchi, C.J.; Rogers, A.; Long, S.P.; Ort, D.R. Elevated $\mathrm{CO}_{2}$ effects on plant carbon, nitrogen, and water relations: Six important lessons from FACE. J. Exp. Bot. 2009, 60, 2859-2876. [CrossRef]

125. Bloom, A.J.; Asensio, J.S.R.; Randall, L.; Rachmilevitch, S.; Cousins, A.B.; Carlisle, E.A. $\mathrm{CO}_{2}$ enrichment inhibits shoot nitrate assimilation in $C_{3}$ but not $C_{4}$ plants and slows growth under nitrate in $C_{3}$ plants. Ecology 2012, 93, 355-367. [CrossRef] [PubMed]

126. Acosta, K.; Xu, J.; Gilbert, S.; Denison, E.; Brinkman, T.; Lebeis, S.; Lam, E. Duckweed hosts a taxonomically similar bacterial assemblage as the terrestrial leaf microbiome. PLoS ONE 2020, 15, e0228560. [CrossRef] [PubMed]

127. Ishizawa, H.; Kuroda, M.; Inoue, D.; Morikawa, M.; Ike, M. Community dynamics of duckweed-associated bacteria upon inoculation of plant growth-promoting bacteria. FEMS Microbiol. Ecol. 2020, 96, fiaa101. [CrossRef]

128. O'Brien, A.M.; Laurich, J.; Lash, E.; Frederickson, M.E. Mutualistic outcomes across plant populations, microbes, and environments in the duckweed Lemna minor. Microb. Ecol. 2020, 80, 384-397. [CrossRef]

129. Zuberer, D.A. Nitrogen fixation (acetylene reduction) associated with duckweed (Lemnaceae) mats. Appl. Environ. Microbiol. 1982, 43, 823-828. [CrossRef] 
130. Ishizawa, H.; Kuroda, M.; Morikawa, M.; Ike, M. Evaluation of environmental bacterial communities as a factor affecting the growth of duckweed Lemna minor. Biotechnol. Biofuels 2017, 10, 62. [CrossRef]

131. Toyama, T.; Kuroda, M.; Ogata, Y.; Hachiya, Y.; Quach, A.; Tokura, K.; Tanaka, Y.; Mori, K.; Morikawa, M.; Ike, M. Enhanced biomass production of duckweeds by inoculating a plant growth-promoting bacterium, Acinetobacter calcoaceticus P23, in sterile medium and non-sterile environmental waters. Water Sci. Technol. 2017, 76, 1418-1428. [CrossRef]

132. Yamakawa, Y.; Jog, R.; Morikawa, M. Effects of co-inoculation of two different plant growth-promoting bacteria on duckweed. Plant Growth Regul. 2018, 86, 287-296. [CrossRef]

133. Khairina, Y.; Jog, R.; Boonmak, C.; Toyama, T.; Oyama, T.; Morikawa, M. Indigenous bacteria, an excellent reservoir of functional plant growth promoters for enhancing duckweed biomass yield on site. Chemosphere 2021, 268, 129247. [CrossRef]

134. Quisehuatl-Tepexicuapan, E.; Ferrera-Cerrato, R.; Silva-Rojas, H.V.; Rodriguez-Zaragoza, S.; Alarcón, A.; Almaraz-Suárez, J.J. Free-living culturable bacteria and protozoa from the rhizoplanes of three floating aquatic plant species. Plant Biosyst. 2014, 150, 855-865. [CrossRef]

135. Grant, A.; Rémond, M.; Starke-Peterkovic, T.; Hinde, R. A cell signal from the coral Plesiastrea versipora reduces starch synthesis in its symbiotic alga, Symbiodinium sp. Comp. Biochem. Physiol.-A Mol. Integr. Physiol. 2006, 144, 458-463. [CrossRef]

136. Grant, A.; People, J.; Rémond, M.; Frankland, S.; Hinde, R. How a host cell signalling molecule modifies carbon metabolism in symbionts of the coral Plesiastrea versipora. FEBS J. 2013, 280, 2085-2096. [CrossRef] [PubMed]

137. Stefan, M.; Munteanu, N.; Stoleru, V.; Mihasan, M.; Hritcu, L. Seed inoculation with plant growth promoting rhizobacteria enhances photosynthesis and yield of runner bean (Phaseolus coccineus L.). Sci. Hortic. 2013, 151, 22-29. [CrossRef]

138. Adams, W.W., III; Stewart, J.J.; Polutchko, S.K.; Demmig-Adams, B. Leaf vasculature and the upper limit of photosynthesis. In The Leaf: A Platform for Performing Photosynthesis, Advances in Photosynthesis and Respiration; Adams, W.W., III, Terashima, I., Eds.; Springer: Cham, Switzerland, 2018; Volume 44, pp. 27-54. [CrossRef]

139. Vacheron, J.; Desbrosses, G.; Bouffaud, M.L.; Touraine, B.; Moënne-Loccoz, Y.; Muller, D.; Legendre, L.; Wisniewski-Dyé, F.; Prigent-Combaret, C. Plant growth-promoting rhizobacteria and root system functioning. Front. Plant Sci. 2013, 4, 356. [CrossRef]

140. Ortíz, J.; Sanhueza, C.; Romero-Munar, A.; Hidalgo-Castellanos, J.; Castro, C.; Bascuñán-godoy, L.; de la Peña, T.C.; López-Gómez, M.; Florez-Sarasa, I.; Del-Saz, N.F. In Vivo metabolic regulation of alternative oxidase under nutrient deficiency-interaction with arbuscular mycorrhizal fungi and Rhizobium bacteria. Int. J. Mol. Sci. 2020, 21, 4201. [CrossRef]

141. Kramer, D.M.; Avenson, T.J.; Edwards, G.E. Dynamic flexibility in the light reactions of photosynthesis governed by both electron and proton transfer reactions. Trends Plant Sci. 2004, 9, 349-357. [CrossRef] [PubMed]

142. Ivanov, A.G.; Rosso, D.; Savitch, L.V.; Stachula, P.; Rosembert, M.; Oquist, G.; Hurry, V.; Hüner, N.P.A. Implications of alternative electron sinks in increased resistance of PSII and PSI photochemistry to high light stress in cold-acclimated Arabidopsis thaliana. Photosynth. Res. 2012, 113, 191-206. [CrossRef]

143. Blanco, N.E.; Ceccoli, R.D.; Vía, M.V.D.; Voss, I.; Segretin, M.E.; Bravo-Almonacid, F.F.; Melzer, M.; Hajirezaei, M.-R.; Scheibe, R.; Hanke, G.T. Expression of the minor isoform pea ferredoxin in tobacco alters photosynthetic electron qartitioning and enhances cyclic electron flow. Plant Physiol. 2013, 161, 866-879. [CrossRef] [PubMed]

144. Courteille, A.; Vesa, S.; Sanz-Barrio, R.; Cazalé, A.-C.; Becuwe-Linka, N.; Farran, I.; Havaux, M.; Rey, P.; Rumeau, D. Thioredoxin $\mathrm{m} 4$ controls photosynthetic alternative electron pathways in Arabidopsis. Plant Physiol. 2013, 161, 508-520. [CrossRef]

145. Strand, D.D.; Fisher, N.; Kramer, D.M. Distinct energetics and regulatory functions of the two major cyclic electron flow pathways in chloroplasts. In Chloroplasts: Current Research and Future Trends; Kirchhoff, H., Ed.; Caister Academic Press: Norfolk, UK, 2016; pp. 89-100. [CrossRef]

146. Kawashima, R.; Sato, R.; Harada, K.; Masuda, S. Relative contributions of PGR5- and NDH-dependent photosystem I cyclic electron flow in the generation of a proton gradient in Arabidopsis chloroplasts. Planta 2017, 246, 1045-1050. [CrossRef]

147. Yoshida, K.; Terashima, I.; Noguchi, K. Up-regulation of mitochondrial alternative oxidase concomitant with chloroplast overreduction by excess light. Plant Cell Physiol. 2007, 48, 606-614. [CrossRef] [PubMed]

148. Yoshida, K.; Watanabe, C.K.; Terashima, I.; Noguchi, K. Physiological impact of mitochondrial alternative oxidase on photosynthesis and growth in Arabidopsis thaliana. Plant Cell Environ. 2011, 34, 1890-1899. [CrossRef]

149. Vishwakarma, A.; Bashyam, L.; Senthilkumaran, B.; Scheibe, R.; Padmasree, K. Physiological role of AOX1a in photosynthesis and maintenance of cellular redox homeostasis under high light in Arabidopsis thaliana. Plant Physiol. Biochem. 2014, 81, 44-53. [CrossRef]

150. Vishwakarma, A.; Tetali, S.D.; Selinski, J.; Scheibe, R.; Padmasree, K. Importance of the alternative oxidase (AOX) pathway in regulating cellular redox and ROS homeostasis to optimize photosynthesis during restriction of the cytochrome oxidase pathway in Arabidopsis thaliana. Ann. Bot. 2015, 116, 555-569. [CrossRef]

151. Shapiguzov, A.; Vainonen, J.P.; Hunter, K.; Tossavainen, H.; Tiwari, A.; Järvi, S.; Hellman, M.; Aarabi, F.; Alseekh, S.; Wybouw, B.; et al. Arabidopsis RCD1 coordinates chloroplast and mitochondrial functions through interaction with ANAC transcription factors. eLife 2019, 8, e43284. [CrossRef]

152. Voss, I.; Sunil, B.; Scheibe, R.; Raghavendra, A.S. Emerging concept for the role of photorespiration as an important part of abiotic stress response. Plant Biol. 2013, 15, 713-722. [CrossRef] [PubMed]

153. Scheibe, R. Maintaining homeostasis by controlled alternatives for energy distribution in plant cells under changing conditions of supply and demand. Photosynth. Res. 2019, 139, 81-91. [CrossRef] [PubMed] 
154. Wang, J.; Cheung, M.; Rasooli, L.; Amirsadeghi, S.; Vanlerberghe, G.C. Plant respiration in a high $\mathrm{CO}_{2}$ world: How will alternative oxidase respond to future atmospheric and climatic conditions? Can. J. Plant Sci. 2014, 94, 1091-1101. [CrossRef]

155. Noguchi, K.O.; Terashima, I. Responses of spinach leaf mitochondria to low N availability. Plant Cell Environ. 2006, 29, 710-719. [CrossRef] [PubMed] 